\title{
Hemodiyaliz Hastalarında Semptom Yönetiminde Tamamlayıcı ve İntegratif Yaklaşımlar: Sistematik Bir Derleme
} $\infty$

\author{
Hacer EROĞLU1 ${ }^{1}$ Zehra GÖK METIN²
}

\section{öz}

Amaç: Bu sistematik derleme, tamamlayıcı ve integratif yaklaşımların hemodiyaliz hastalarının semptomlarına etkilerini değerlendirmek amacıyla yapılmıştır.

Gereç ve Yöntem: Bu derleme, Cochrane Sistematik Derleme Rehberi temel alınarak yapılandırılmıştır. Konuyla ilgili tam metinler Cochrane, PubMed, ScienceDirect, Türk Medline ve ULAKBIM Tıp'ı içeren beş veri tabanı üzerinden 01.01.2010-01.08.2020 tarihleri arasında yapılan çalışmalar taranmıştır. Kriterleri karşılayan otuz bir çalışma dahil edilmiştir.

Bulgular: Derleme kapsamına alınan, hemodiyaliz hastalarında yürütülen çalışma bulgularına göre, hastaların semptom yönetiminde akupunktur $(n=3)$, aromaterapi masajı $(n=4)$, Benson gevşeme tekniği $(n=9)$, masaj $(n=5)$, meditasyon $(n=1)$, progresif gevşeme egzersizi $(n=3)$ ve refleksoloji $(n=6)$ gibi yaklaşımların uygulandığı görülmüştür. Çalışmaların çoğunun $(n=21)$ İran'da yürütüldüğü, randomize kontrollü $(n=27)$ ve yarı-deneysel $(n=4)$ tasarıma sahip olduğu görülmüştür. Araştırmaların yorgunluk $(n=15)$, stres, anksiyete, depresyon $(n=9)$, uyku sorunları $(n=5)$ ve ağrı $(n=5)$ gibi semptomlara yoğunlaştığı belirlenmiştir. Araştırmaların çoğunda $(n=30, \% 96,8)$ hemodiyaliz hastalarının semptom puanlarında anlamlı düzeyde azalma olduğu bildirilmiştir. Sonuç: Bu çalışmada tamamlayıcı ve integratif yaklaşımların etkilerini doğrulayan yeni randomize kontrollü araştırmaların yapılması ve elde edilen sonuçlar doğrultusunda bu yaklaşımların hemodiyaliz semptomlarını hafifletmede yaygınlaştırılması önerilmiştir.

Anahtar kelimeler: Hemodiyaliz, semptom, sistematik derleme, tamamlayıcı terapiler

\begin{abstract}
Complementary and Integrative Approaches to Symptom Management in Patients Undergoing Hemodialysis: A Systematic Review

Aim: This systematic review aimed to evaluate the effects of complementary and integrative approaches on symptoms of patients undergoing hemodialysis.

Material and Methods: The review was structured on the basis of the Cochrane Systematic Review Guide. Five databases, including Cochrane, PubMed, Science Direct, Turk Medline, and ULAKBIM, were searched for relevant full-text articles between 01.01.2010 and 01.08.2020. Thirty-one studies meeting the criteria were included.

Results: According to the study findings included in the review; acupuncture $(n=3)$, aromatherapy massage $(n=4)$, Benson relaxation technique $(n=9)$, massage $(n=5)$, meditation $(n=1)$, progressive relaxation exercises $(n=3)$, and reflexology $(n=6)$ were used in symptom management of patients undergoing hemodialysis. It was determined that most of the studies $(n=21)$ were conducted in Iran and had a randomized controlled ( $n=27)$ and quasi-experimental design $(n=4)$. The studies focused on symptoms including fatigue $(n=15)$, stress, anxiety, and depression $(n=9)$, sleep problems $(n=5)$, and pain $(n=5)$. Most of the studies $(n=30,96.8 \%)$ reported that a significant decrease in symptom scores of patients undergoing hemodialysis.

Conclusion: This review recommends conducting new randomized controlled studies to confirm the effects of complementary and integrative approaches and expand these approaches to alleviate hemodialysis symptoms in line with the results obtained.
\end{abstract}

Keywords: Complementary therapies, hemodialysis, symptoms, systematic review

\footnotetext{
${ }^{1}$ Uzm. Hem., Ankara Eğitim ve Araştırma Hastanesi, Ankara, Türkiye, E-mail: haceroturmaz@gmail.com, Tel: 055589962 22, ORCID: 0000-0002-4708-8447 2Doç. Dr., Hacettepe Üniversitesi, Hemşirelik Fakültesi, İ̧̧ Hastalıkları Hemşireliği Anabilim Dalı, Ankara, Türkiye, E-mail: zehragok85@hotmail.com, Tel: 0312 305 15 80/150, ORCID: 0000-0003-0311-9982

Geliş Tarihi:08 Kasım 2020, Kabul Tarihi: 11 Haziran 2021

Atıf/Citation: Eroğlu H., Gök Metin Z. Hemodiyaliz Hastalarında Semptom Yönetiminde Tamamlayııı ve İntegratif Yaklaşımlar: Sistematik Bir Derleme. Hacettepe Üniversitesi Hemşirelik Fakültesi Dergisi 2021;8(3):252-268. DOI:
} 


\section{GíRiş}

Kronik böbrek hastalığı $(K B H)$, geri dönüşümsüz nefron hasarı ve filtrasyon yeteneğindeki gerileme sonucu böbreğin fonksiyonlarını tam ya da kısmi olarak yerine getiremediği, hastaların yaşam kalitesini bozan, morbidite ve mortalite oranını arttıran önemli bir hastalıktır ${ }^{1,2}$. Glomerüler filtrasyon hızı (GFH)'nın $15 \mathrm{ml} / \mathrm{dk}^{\prime}$ nın altına indiği, endojen böbrek fonksiyonunun geri dönüşsüz kaybıyla karakterize durum kronik böbrek hastalığının beşinci evresi olan son dönem böbrek yetmezliği (SDBY) şeklinde tanımlanmaktadır. Hastalar bu evrede yaşamlarını devam ettirebilmek amacıyla Renal Replasman Tedavi (RRT) seçeneklerinden biri olan hemodiyalize (HD) başvurmak durumunda kalmaktadır ${ }^{3}$. Ulusal Nefroloji, Diyaliz ve Transplantasyon Kayıt Sistemi Raporu'na göre ülkemizde 2018 yılı sonu itibariyle, KBH olan hastaların yaklaşık \%88'inin haftada 3 seans HD tedavisi aldığı bildirilmiştir ${ }^{4}$. Hemodiyaliz ile vücutta biriken üre, ürik asit ve kreatinin gibi toksik maddelerin ve fazla suyun bir membran aracılığıyla vücuttan uzaklaştırılması sağlanmakta, bu sayede bozulan böbrek fonksiyonlarının bir bölümü düzenlenebilmekte ve hastalar yaşamlarını sürdürebilmektedir ${ }^{5}$. Buna rağmen HD ilişkili semptomlar nedeniyle hastaların günlük yaşam aktiviteleri sınırlanmakta ve yaşam kaliteleri giderek azalmaktadır ${ }^{6}$. Hemodiyaliz hastalarında görülen fiziksel semptomlar; yorgunluk (\%60-97), uyku sorunları (\%40-85), kas krampları (\%33-78), vücut ağrıları (\%76), nefes darlığı (\%71), iştahsızlık (\%67), bulantı ve kusma (\%67), kuru ve kaşıntılı cilt (\%52), hipotansiyon (\%20-30) olarak belirtilmiştir7,8. Depresyon (\%20-90) ve anksiyete (\%64) ise en sık görülen duygu durum semptomları olarak bildirilmiştir ${ }^{9}$. Hemodiyaliz hastaları tarafından yukarıda belirtilen semptomların yönetiminde mevcut tedavi yöntemlerinden yeterince doyum alamama, tedavi maliyetlerinin daha düşük olması, uygulanan farmakolojik tedavilere göre yan etkilerinin daha az olması, manevi olarak iyi hissetme, hastalıkları kontrol altında tutma ve bağışıklık sistemini güçlendirme gibi nedenlerle tamamlayıcı ve integratif yöntemler sıklıkla tercih edilmeye başlanmıştır ${ }^{10}$. Literatür incelendiğinde, son yıllarda hastaların HD tedavisine bağı gelişen semptomların hafifletilmesinde aromaterapi, masaj, meditasyon, müzik terapi, gevşeme egzersizleri, akupunktur ve refleksoloji gibi farklı tamamlayıcı ve integratif yaklaşımlar kullandığı görülmektedir ${ }^{11,12}$. HD ilişkili semptomların giderilmesi ve kanıta dayalı uygulamaların yaygınlaştırılmasına yönelik günümüzde bu yaklaşımların sonuçlarının incelendiği çok sayıda klinik çalışma yapılmaktadır ${ }^{13,14}$. Bu bilimsel inceleme yazısının sağlık profesyonellerine HD semptomlarının etkin yönetimi konusunda yeni bir perspektif kazandırabileceği öngörülmektedir. Böylelikle HD hastaları tarafından da kolaylıkla uygulanabilen bu tamamlayıcı ve integratif yaklaşımların kullanımının artmasıyla etkili semptom yönetimi sağlanarak hastaların $\mathrm{KBH}$ üzerinde öz denetim kazanmaları, fiziksel ve psikososyal iyilik hallerinin ve yaşam kalitelerinin arttırıması sağlanabilecektir.

\section{Araştırmanın Amacı}

$\mathrm{Bu}$ sistematik derlemenin amacı, ağrı, yorgunluk, uyku bozuklukları, kaşıntı, stres, anksiyete ve depresyon gibi semptomlar yaşayan HD hastalarının tedavi ve bakımını üstlenen sağlık profesyonellerinin bu semptomları yönetmek için güncel literatürde yer alan tamamlayıcı ve integratif yaklaşımların sonuçları hakkında bilgilendirilmesidir.

\section{GEREÇ ve YÖNTEM}

\section{Araştırmanın Türü}

$\mathrm{Bu}$ sistematik derlemede Higgins ve Green tarafından yayınlanan Cochrane Sistematik Derleme Rehberi (2011) temel alınmıştır ${ }^{15}$.

Araştırma Sorusunun Belirlenmesi

Araştırma sorusunun belirlenmesi için; araştırma sorusu katılımcıları (P: population), müdahaleleri (I: intervention), karşılaştırma gruplarını (C: comparator), sonuçları (O: outcome/s) ve araştırma desenlerini (S: study design) açıkça tanımlamak için yazarlar tarafından araştırma sorusu bileşenleri (PICOS) oluşturulmuştur (Tablo 1).

Tablo 1. Araştırma Sorusunun Oluşturulması

\begin{tabular}{|l|l|}
\hline Sorunun bileşenleri & Tanım/açıklama \\
\hline P: Hemodiyaliz hastası & ilgilenilen hedef grup \\
\hline I: Uygulanan girişim & $\begin{array}{l}\text { Tamamlayıcı ve integratif } \\
\text { yaklaşıllar } \\
\text { "Akupunktur, aromaterapi masajı, } \\
\text { Benson gevşeme tekniği, klasik } \\
\text { isveç masajı, meditasyon, progresif } \\
\text { kas gevşeme egzersizi ve } \\
\text { refleksoloji” }\end{array}$ \\
\hline C: Karşılaştırma & $\begin{array}{l}\text { Hemodiyaliz hastalarının müdahale } \\
\text { öncesi ölçek puanları } \\
\text { Kontrol grubu ölçek puanları } \\
\text { Bu sistematik derlemeye dahil } \\
\text { edilen tüm çalışmalarda } \\
\text { çalışmaların ilk gününde müdahale } \\
\text { ve kontrol gruplarının ilgili ölçek } \\
\text { puanları araştırmacılar tarafından } \\
\text { değerlendirilmiştir. }\end{array}$ \\
\hline O: Sonuçlar & $\begin{array}{l}\text { Hemodiyaliz hastalarının ölçek } \\
\text { puanları }\end{array}$ \\
\hline S: Çalışmanın tasarımı & $\begin{array}{l}\text { Yarı-deneysel araştırmalar } \\
\text { Randomize kontrollü klinik } \\
\text { araştırmalar } \\
\text { Ön test ve son test kontrollü } \\
\text { araştırmalar }\end{array}$ \\
\hline
\end{tabular}

Literatür Tarama Adımları

Konu ile ilgili öncelikle ön kaynak taraması yapılmış, alanda en çok kullanılan tamamlayıcı ve integratif yaklaşımlar (aromaterapi masajı, klasik masaj, akupunktur, refleksoloji, meditasyon, progresif gevşeme egzersizi (PGE), Benson gevşeme tekniği (BGT) belirlenmiştir. Ardından Cochrane, PubMed, SicenceDirect, Türk Medline ve ULAKBIM Tıp veri tabanları üzerinden İngilizce anahtar kelimeler için Medical Subject Headings (MeSH) dizini, Türkçe anahtar kelimeler için Türkiye Bilim Terimleri (TBT)'de yer alan "aromaterapi masajı", "klasik masaj", "refleksoloji", "meditasyon", "progresif kas gevşeme egzersizi", "Benson gevşeme 
tekniği", "hemodiyaliz", "hemşirelik", "klinik araştırma", nonfarmakolojik" ve "tamamlayıcı ve integratif" anahtar kelimeleri ile ayrı ayrı tarama yapılmıştır. İngilizce anahtar kelimelerde ise Türkçe çeviriler kullanılmıştır (Tablo 2). Hemşirelik alanında HD ilişkili semptomların hafifletilmesinde kullanılan tamamlayıcı ve integratif yaklaşımlara daha geniş bir bakış açısı kazandırabilmek için son on yılı (01.01.2010-01.08.2020) kapsayacak şekilde bu sistematik derleme kaleme alınmıştır.

Tablo 2. Anahtar Kelimelerin Belirlenmesi

\begin{tabular}{|l|l|}
\hline Anahtar kelimeler & Alternatif tarama terimleri \\
\hline "aromaterapi masajı", & "aromatherapy massage", \\
"masaj", "meditasyon", & "massage", "meditation", \\
"progresif kas gevşeme & "progressive muscle \\
egzersizi", "Benson gevşeme & relaxation exercise", "Benson \\
tekniği", "akupunktur", & relaxation technique", \\
"hemodiyaliz", "hemşirelik", & "acupuncture", \\
"klinik & "hemodialysis", "clinical trial”, \\
araştırma", "nonfarmakolojik", & "nursing", and \\
ve "tamamlayıcı ve integratif" & "nonpharmacological", and \\
& "complementary and \\
& integrative" \\
& \\
\hline
\end{tabular}

\section{Dahil Edilme ve Dışlama Kriterleri}

Bu sistematik derlemeye: (1) Deneysel veya yarı-deneysel çalışma tasarımına sahip olan, (2) HD tedavisi alan hastalar üzerinde gerçekleştirilen, (3) en az bir tamamlayıcı ve integratif yaklaşım uygulayan, (4) HD ilişkili semptomlardan birinin düzeyini ölçen, en az bir veri toplama aracı kullanan, (5) Türkçe veya İngilizce yayınlanmış olan ve (6) 01.01.201001.08.2020 yılları arasında gerçekleştirilen araştırmalar dahil edilmiştir. (1) Türkçe ve İngilizce dışında başka bir dilde yayınlanan, (2) deneysel tasarımı olmayan, (3) örnekleminde HD hastası olmayan, (4) HD ilişkili semptomlardan birini değerlendirmeye yönelik spesifik bir ölçüm aracı kullanmayan, (5) 01.01.2010 yılı öncesinde yayınlanmış olan ve (6) sistematik derleme, meta-analiz, olgu raporu, tez çalışması, sempozyum-kongre bildirisi, editöre mektup veya devam eden çalışma niteliğinde olan araştırmalar ise bu sistematik derlemenin kapsamına alınmamıştır.

\section{Araştırmaların Seçilmesi}

Makalenin yazarları tarafından veri tabanları üzerinden yukarıda belirtilen anahtar kelimeler kullanılarak ve yıl seçenekleri filtrelenerek literatür taraması yapılmış ve toplamda 638 adet makaleye ulaşılmıştır. Makaleler başlıklarına göre ayrıştırılmış ve konu ile ilgili olabilecek özetler $(n=90)$ kaydedilmiştir. Ardından yazarlar özetleri incelemişler, dahil edilme ve dışlama kriterlerine göre tekrar ayrıştırılmıştır. Özet okuması sonrasında, sistematik derleme olan $(n=14)$, örnekleminde HD hastası olmayan $(n=33)$ ve deneysel tasarıma sahip olmayan $(n=12)$ toplamda $(n=59)$ araştırma dışlanmıştır. Geriye kalan $(n=31)$ makalenin ise tam metinleri detaylıca okunmuş, tamamı dahil edilme kriterlerini karşıladığı için bu derlemenin kapsamına dahil edilmiştir (Şekil 1).
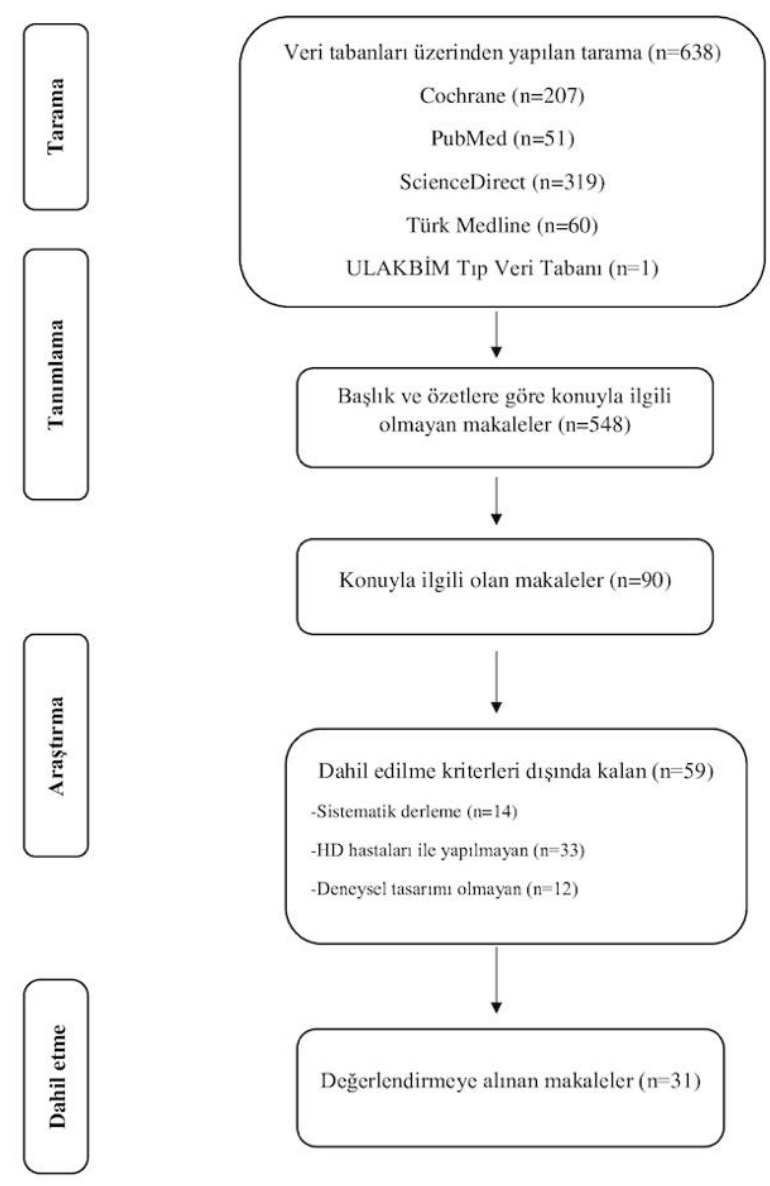

Şekil 1. Makale Seçim Süreci Verilerin Bir Araya Getirilmesi

Bu sistematik derlemeye dahil edilen araştırmalara yönelik verilerin incelenmesi için yazarlar standart bir form geliştirmiştir. İlgili formda araştırmanın numarası, araştırmada kullanılan tamamlayıcı ve integratif yaklaşım, araştırmanın yapıldığı ülke, yılı, yazarları, tasarımı, örneklem büyüklüğü, kadın/erkek katılımcı sayısı, yaş ortalaması/yaş aralığı, uygulama süresi, kullanılan ölçüm araçları ve araştırmanın temel sonuçlarına yönelik bilgiler yer almıştır (Tablo 3).

\section{Araştırmanın Sınırlılıkları}

$\mathrm{Bu}$ sistematik derlemenin bazı sınırlılıkları dikkate alınmalıdır. Literatür taramasının beş veri tabanı üzerinden gerçekleştirilmesi ve tez, editöre mektup, konferans bildirisi gibi gri literatürün dahil edilmemesi önemli bir sınırlılık olarak değerlendirilmelidir. Bunun yanı sıra, bu derleme kapsamına ülkemizde HD hastalarının semptomlarına yönelik tamamlayıcı ve integratif yaklaşımların etkisini inceleyen ve yayınlanmış olan sınırlı sayıda araştırma $(n=6)$ olduğu için çoğunlukla İngilizce yayınlar dahil edilebilmiştir. Tamamlayıcı ve integratif yaklaşımların uygulama ve kullanımlarının ülkeler arasında farklılık göstermesi nedeniyle bu sonuçların dikkatli ve titiz bir şekilde yorumlanması ve genelleştirilmemesi gereklidir. 
Tablo 3. Sistematik Derlemeye Dahil Edilen Araştırmaların Özellikleri ( $n=31)$

\begin{tabular}{|c|c|c|c|c|c|c|c|c|}
\hline $\begin{array}{l}\text { Araştırma } \\
\text { no }\end{array}$ & Ülke /Yıl & Yazarlar & $\begin{array}{l}\text { Kullanılan Tamamlayıcı ve } \\
\text { İntegratif Yaklaşım ve } \\
\text { Uygulama Bölgesi }\end{array}$ & $\begin{array}{l}\text { Araştırma } \\
\text { tasarımı }\end{array}$ & $\begin{array}{l}\text { Örneklem } \\
\text { büyüklüğü }\end{array}$ & Uygulama süresi & $\begin{array}{l}\text { Kullanılan Ölçüm } \\
\text { Araçları }\end{array}$ & Sonuçlar \\
\hline 1 & $\begin{array}{l}\text { İran, } \\
2016\end{array}$ & $\begin{array}{l}\text { Hadadian ve } \\
\text { ark. }\end{array}$ & $\begin{array}{l}\text { Akupunktur /(ST36), (SP6), } \\
\text { (LI4) noktaları }\end{array}$ & RKÇ & $\begin{array}{l}56 \text { HD hastası } \\
\text { Kadın: } 18 \\
\text { Erkek: } 38 \\
\text { Yaş ortalaması: } 52\end{array}$ & $\begin{array}{l}\text { Altı akupunktur noktasına } 5 \text { hafta } \\
\text { boyunca haftada } 2-3 \text { kez çift taraflı } \\
\text { olarak } 5 \text { dakika TEAS (akupunktur } \\
\text { noktası başına } 50 \text { saniye). } \\
\text { Uygulamalar, HD seansının } \\
\text { başlamasından } 2 \text { saat sonra } \\
\text { yapılmıştır. }\end{array}$ & $\begin{array}{l}\text {-Kısa Yorgunluk } \\
\text { Envanteri }\end{array}$ & $\begin{array}{l}\text { Müdahale sonrası } \\
\text { TEAS grubunun } \\
\text { yorgunluk } \\
\text { puanlarında anlamlı } \\
\text { düzeyde azalma } \\
\text { olduğu bildirilmiştir. }\end{array}$ \\
\hline 2 & $\begin{array}{l}\text { Türkiye, } \\
2016\end{array}$ & $\begin{array}{l}\text { Kılıç Akça ve } \\
\text { ark. }\end{array}$ & $\begin{array}{l}\text { Akupresür ya da TEAS / } \\
\text { (LI-11) noktası }\end{array}$ & RKÇ & 75 HD hastası & $\begin{array}{l}\text { İki müdahale grubuna, } 4 \text { hafta } \\
\text { haftada } 3 \text { seans akupresür ya da } \\
\text { TEAS tedavileri uygulanmıştır. }\end{array}$ & $\begin{array}{l}\text {-Görsel Analog Ölçek } \\
\text { (VAS) }\end{array}$ & $\begin{array}{l}\text { Akupresür ve TEAS } \\
\text { gruplarındaki } \\
\text { hastaların, kontrol } \\
\text { grubundaki hastalara } \\
\text { göre kaşıntıdan } \\
\text { kaynaklanan } \\
\text { rahatsızlık } \\
\text { düzeylerinde azalma } \\
\text { olduğu, akupunktur } \\
\text { ve TEAS grupları } \\
\text { arasında ise } \\
\text { istatistiksel açıdan bir } \\
\text { fark olmadığı } \\
\text { bildirilmiştir. }\end{array}$ \\
\hline 3 & $\begin{array}{l}\text { Tayvan, } \\
2018\end{array}$ & Tsai ve ark. & $\begin{array}{l}\text { Akupunktur/ } \\
\text { KI1 (bilateral) ve CV4 } \\
\text { noktaları }\end{array}$ & RKÇ & $\begin{array}{l}27 \text { HD hastası } \\
\text { Kadın: } 9 \\
\text { Erkek: } 18 \\
\text { Yaş ortalaması: } 60\end{array}$ & $\begin{array}{l}4 \text { hafta boyunca haftada } 3 \text { kez her } \\
\text { HD seansında iki gruba da dört saat } \\
\text { HAT uygulanmıştır. Üç noktaya } \\
\text { akupunktur noktasına yerleştirilen } \\
\text { yamalar her seanstan } 10 \text { dakika } \\
\text { önce uygulanmış ve HD sonunda } \\
\text { çıkarımıştır. Plasebo grubunda } \\
\text { kullanılan yamalar HAT grubundaki } \\
\text { yamalarla görünüş olarak aynı olsa } \\
\text { da kahverengi kil ile yapılmışıtır. }\end{array}$ & $\begin{array}{l}\text {-Kan basıncı ölçümü } \\
\text { - Görsel Analog } \\
\text { Skala (VAS) }\end{array}$ & $\begin{array}{l}\text { Müdahalenin } \\
\text { sonunda, HAT } \\
\text { grubundaki hastaların } \\
\text { plasebo grubana göre } \\
\text { anlamlı düzeyde daha } \\
\text { düşük intradiyalitik } \\
\text { hipotansiyon epizod } \\
\text { sıklığı, yorgunluk } \\
\text { derecesindeki } \\
\text { iyileşmenin anlamlı } \\
\text { düzeyde arttığı ve } \\
\text { diyaliz sonrası } \\
\text { yorgunluktan } \\
\text { kurtulma süresinin } \\
\text { daha kısa olduğu } \\
\text { rapor edilmiştir. }\end{array}$ \\
\hline
\end{tabular}


Tablo 3. Sistematik Derlemeye Dahil Edilen Araştırmaların Özellikleri ( $n=31$ ) (devamı)

\begin{tabular}{|c|c|c|c|c|c|c|c|c|}
\hline 4 & $\begin{array}{l}\text { İran, } \\
2010\end{array}$ & $\begin{array}{l}\text { Shahgholian ve } \\
\text { ark. }\end{array}$ & $\begin{array}{l}\text { Aromaterapi Masajı/ } \\
\text { Fistül bulunmayan } \\
\text { koldaki el }\end{array}$ & $\begin{array}{l}\text { Non-randomize } \\
\text { ön test-son test } \\
\text { karşılaşıımalı } \\
\text { çalış̧ma }\end{array}$ & $\begin{array}{l}20 \mathrm{HD} \text { hastası } \\
\text { Kadın: } 8 \\
\text { Erkek: } 12 \\
\text { Yaş ortalaması: } 50\end{array}$ & $\begin{array}{l}2 \text { hafta boyunca haftada üç kez, } \\
\text { toplam } 6 \text { seans, } \% 5 \\
\text { konsantrasyonda } 3-5 \text { ml lavanta, } \\
\text { nane ve çay ağacı yağları ile } 7 \text { dk. el } \\
\text { masajı yapılmıştır. }\end{array}$ & -Kaşıntı Skalası & $\begin{array}{l}\text { Uygulama öncesi ve } \\
\text { sonrası kaşıntı } \\
\text { puanlarının } \\
\text { ortalaması arasında } \\
\text { anlamlı bir fark } \\
\text { olduğu bildirilmiştir. }\end{array}$ \\
\hline 5 & $\begin{array}{l}\text { Türkiye, } \\
2015\end{array}$ & Biçer ve ark. & Aromaterapi Masajı/Yüz & $\begin{array}{l}\text { Tek gruplu yarı- } \\
\text { deneysel ön- } \\
\text { test son test } \\
\text { karşıllaştırmalı } \\
\text { çalış̧ma }\end{array}$ & 25 HD hastası & $\begin{array}{l}\text { Tüm hastalara, } 3 \text { hafta boyunca } \\
\text { haftada } 3 \text { gün, her diyaliz seansının } \\
\text { ilk saatinde } 10 \text { dakika boyunca } \\
\text { aromaterapi masajı yapmışlardır. }\end{array}$ & $\begin{array}{l}\text {-Görsel Analog Skala } \\
\text { (VAS) }\end{array}$ & $\begin{array}{l}\text { Uygulama sonrasında } \\
\text { ağrı puanlarının } \\
\text { istatistiksel olarak } \\
\text { anlamlı azalma } \\
\text { gösterdiğini } \\
\text { belirtmişlerdir. }\end{array}$ \\
\hline 6 & $\begin{array}{l}\text { Türkiye, } \\
2018\end{array}$ & Arslan ve ark. & $\begin{array}{l}\text { Aromaterapi Masajı/ Her } \\
\text { iki el }\end{array}$ & RKÇ & $\begin{array}{l}44 \mathrm{HD} \text { hastası } \\
\text { Kadın: } 14 \\
\text { Erkek: } 30 \\
\text { Yaş ortalaması: } 57\end{array}$ & $\begin{array}{l}\text { Müdahale grubundaki hastalara } 4 \\
\text { hafta boyunca } 12 \text { seans } \\
\text { aromaterapi el masajı (her bir el için } \\
5 \text { dakika olacak şekilde toplamda } 10 \\
\text { dakika olarak) \%2 lavanta yağı ve } \\
\text { tatlı badem yağı }(1 \mathrm{ml} \text { ) ile öfloraj } \\
\text { tekniğini kullanarak uygulamışlardır. }\end{array}$ & $\begin{array}{l}\text {-Sıkıntı } \\
\text { Termometresi } \\
\text {-Pittsburgh Uyku } \\
\text { Kalite İndeksi }\end{array}$ & $\begin{array}{l}\text { Müdahale grubunda } \\
\text { kontrol grubuna göre } \\
\text { sıkıntı puan ve uyku } \\
\text { kalitesi puan } \\
\text { ortalamalarında } \\
\text { istatistiksel olarak } \\
\text { anlamlı bir azalma } \\
\text { olduğu bildirilmiştir. }\end{array}$ \\
\hline 7 & $\begin{array}{l}\text { Iran, } \\
2020\end{array}$ & Varaei ve ark. & $\begin{array}{l}\text { Aromaterapi Masajı ve } \\
\text { İnhalasyonu }\end{array}$ & RKÇ & 96 HD hastası & $\begin{array}{l}\text { Hastalar inhalasyon aromaterapi, } \\
\text { masaj aromaterapi ve kontrol } \\
\text { gruplarına ayrılmıştır. } \\
16 \text { hafta boyunca lavanta ve tatlı } \\
\text { portakal yağı karışımının inhalasyon } \\
\text { ve masaj aromaterapi uygulamaları } \\
\text { yapılmıştır. }\end{array}$ & $\begin{array}{l}\text { Rhoten yorgunluk } \\
\text { ölçeği }\end{array}$ & $\begin{array}{l}\text { Her iki deney } \\
\text { grubundaki yorgunluk } \\
\text { seviyelerinin kontrol } \\
\text { grubuna göre anlamlı } \\
\text { derecede düşük } \\
\text { olduğu, ancak } \\
\text { aromaterapi } \\
\text { masajının yorgunluk } \\
\text { üzerindeki etkilerinin } \\
\text { inhalasyon } \\
\text { aromaterapisinin } \\
\text { etkilerinden daha } \\
\text { güçlü olduğu } \\
\text { bildirilmiştir. }\end{array}$ \\
\hline 8 & $\begin{array}{l}\text { İran, } \\
2013\end{array}$ & Mahdavi ve ark. & BGT & RKÇ & $\begin{array}{l}80 \text { HD hastası } \\
\text { Kadın: } 44 \\
\text { Erkek: } 36 \\
\text { Yaş ortalaması: } 47\end{array}$ & $\begin{array}{l}\text { Müdahale grubunda bulunan } \\
\text { hastalar günde } 2 \text { kez } 15 \mathrm{dk} \text {. Benson } \\
\text { gevşeme tekniği uygulamışlardır. }\end{array}$ & $\begin{array}{l}\text {-Depresyon } \\
\text { Anksiyete Stres } \\
\text { Ölçeği-21 }\end{array}$ & $\begin{array}{l}\text { Müdahale grubunda } \\
\text { uygulama öncesi ve } \\
\text { sonrası stres ve } \\
\text { anksiyete } \\
\text { düzeylerinde anlamlı } \\
\text { farklılıklar varken; } \\
\text { depresyonda anlamlı } \\
\text { bir fark olmadığı } \\
\text { bulunmuştur. }\end{array}$ \\
\hline
\end{tabular}


Tablo 3. Sistematik Derlemeye Dahil Edilen Araştırmaların Özellikleri ( $n=31)$ (devamı)

\begin{tabular}{|c|c|c|c|c|c|c|c|c|}
\hline 9 & $\begin{array}{l}\text { İran, } \\
2014\end{array}$ & Gorji ve ark. & BGT & RKÇ & $\begin{array}{l}80 \text { HD hastası } \\
\text { Kadın: } 44 \\
\text { Erkek: } 36 \\
\text { Yaş ortalaması: } 47\end{array}$ & $\begin{array}{l}\text { Müdahale grubunda bulunan } \\
\text { hastalar günde } 2 \text { kez } 15 \mathrm{dk} \text {. Benson } \\
\text { gevşeme tekniği uygulamışlardır. }\end{array}$ & $\begin{array}{l}\text {-Depresyon } \\
\text { Anksiyete Stres } \\
\text { Ölçeği-21 } \\
\text {-McGill Ağrı Anketi }\end{array}$ & $\begin{array}{l}\text { Müdahale grubunda } \\
\text { uygulama öncesi ve } \\
\text { sonrası ağrı algısı, } \\
\text { stres ve anksiyete } \\
\text { düzeyleri arasında } \\
\text { anlamlı farklılıklar } \\
\text { olduğu bildirilmiştir. }\end{array}$ \\
\hline 10 & $\begin{array}{l}\text { İran, } \\
2013\end{array}$ & Rambod ve ark. & BGT & RKÇ & $\begin{array}{l}86 \text { HD hastası } \\
\text { Kadın: } 33 \\
\text { Erkek: } 53 \\
\text { Yaş ortalaması: } 49\end{array}$ & $\begin{array}{l}\text { Müdahale grubundaki hastalar, } \\
\text { aldıkları BGT eğitimi sonrasında } \\
\text { evde CD kaydından } 8 \text { hafta boyunca } \\
\text { her gün günde iki kez } 20 \text { dakika } \\
\text { Benson gevşeme tekniğini } \\
\text { uygulamışlardır. }\end{array}$ & $\begin{array}{l}\text {-Pittsburgh Uyku } \\
\text { Kalitesi İndeksi }\end{array}$ & $\begin{array}{l}\text { Müdahale grubunda } \\
\text { uygulama öncesi ve } \\
\text { sonrası uyku } \\
\text { kalitesinde } \\
\text { iyileşmeler olduğu } \\
\text { bildirilmiştir. }\end{array}$ \\
\hline 11 & $\begin{array}{l}\text { İran, } \\
2014\end{array}$ & Rambod ve ark. & BGT & RKÇ & $\begin{array}{l}86 \text { HD hastası } \\
\text { Kadın: } 33 \\
\text { Erkek: } 53 \\
\text { Yaş ortalaması: } 50\end{array}$ & $\begin{array}{l}\text { Müdahale grubundaki hastalar, } \\
\text { aldıkları BGT eğitimi sonrasında } \\
\text { evde CD kaydından } 8 \text { hafta boyunca } \\
\text { her gün günde iki kez } 20 \text { dakika } \\
\text { Benson gevşeme tekniğini } \\
\text { uygulamışlardır. }\end{array}$ & $\begin{array}{l}\text { - Ağrı Sayısal } \\
\text { Derecelendirme } \\
\text { Ölçeği } \\
\text {-Yaşam Kalitesi } \\
\text { Indeksi-Diyaliz } \\
\text { Versiyonu } \\
\end{array}$ & $\begin{array}{l}\text { Müdahale grubunda } \\
\text { ağrının önemli ölçüde } \\
\text { hafiflediği ve yaşam } \\
\text { kalitesini iyileştiği } \\
\text { bildirilmiştir. }\end{array}$ \\
\hline 12 & $\begin{array}{l}\text { İran, } \\
2014\end{array}$ & Koushan ve ark. & BGT & RKÇ & 65 HD hastası & $\begin{array}{l}\text { Müdahale grubunda bulunan } \\
\text { hastalar günde } 2 \text { kez } 15 \mathrm{dk} \text {. Benson } \\
\text { gevşeme tekniği uygulamışlardır. }\end{array}$ & $\begin{array}{l}\text {-Kısa Yorgunluk } \\
\text { Envanteri }\end{array}$ & $\begin{array}{l}\text { Müdahale grubunda } \\
\text { uygulama öncesi ve } \\
\text { sonrası yorgunluk } \\
\text { puanları arasında } \\
\text { anlamlı bir fark } \\
\text { olduğu belirtilmiştir. }\end{array}$ \\
\hline 13 & $\begin{array}{l}\text { İran, } \\
2015\end{array}$ & $\begin{array}{l}\text { Heshmatifar ve } \\
\text { ark }\end{array}$ & BGT & RKÇ & $\begin{array}{l}65 \text { HD hastası } \\
\text { Kadın: } 14 \\
\text { Erkek: } 51 \\
\text { Yaş ortalaması: } 48\end{array}$ & $\begin{array}{l}\text { Müdahale grubunda bulunan } \\
\text { hastalar günde } 2 \text { kez } 20 \mathrm{dk} \text {. Benson } \\
\text { gevşeme tekniği uygulamışlardır. }\end{array}$ & $\begin{array}{l}\text {-Beck Depresyon } \\
\text { Envanteri }\end{array}$ & $\begin{array}{l}\text { Benson gevşeme } \\
\text { tekniğinin HD } \\
\text { hastalarında } \\
\text { depresyonu } \\
\text { azaltmada etkili bir } \\
\text { yöntem olduğu } \\
\text { bildirilmiştir. }\end{array}$ \\
\hline 14 & $\begin{array}{l}\text { İran, } \\
2016\end{array}$ & Otaghi ve ark. & BGT & RKÇ & 70 HD hastası & $\begin{array}{l}\text { Müdahale grubunda bulunan } \\
\text { hastalar günde } 2 \text { kez } 15 \mathrm{dk} \text {. Benson } \\
\text { gevşeme tekniği uygulamışlardır. }\end{array}$ & $\begin{array}{l}\text {-Depresyon } \\
\text { Anksiyete Stres } \\
\text { Ölçeği-21 }\end{array}$ & $\begin{array}{l}\text { Uygulamadan sonra } \\
\text { hastaların depresyon } \\
\text { düzeylerinde gruplar } \\
\text { arasında fark yokken; } \\
\text { stres ve anksiyete } \\
\text { düzeylerinde anlamlı } \\
\text { düzeyde azalma } \\
\text { olduğu bildirilmiştir. }\end{array}$ \\
\hline
\end{tabular}


Tablo 3. Sistematik Derlemeye Dahil Edilen Araştırmaların Özellikleri ( $n=31)$ (devamı)

\begin{tabular}{|c|c|c|c|c|c|c|c|c|}
\hline 15 & $\begin{array}{l}\text { İran, } \\
2018\end{array}$ & $\begin{array}{l}\text { Hassanzadeh ve } \\
\text { ark }\end{array}$ & $\begin{array}{l}\text { Aromaterapi İnhalasyon } \\
\text { ya da BGT }\end{array}$ & RKÇ & $\begin{array}{l}105 \text { HD hastası } \\
\text { Kadın: } 45 \\
\text { Erkek: } 60 \\
\text { Yaş ortalaması: } 42\end{array}$ & $\begin{array}{l}\text { Uygulama, her iki müdahale grubu } \\
\text { için de } 4 \text { hafta boyunca günde iki } \\
\text { kez tekrarlanmıştır. Aromaterapi } \\
\text { grubunda, \%5 lavanta yağı ( } 2 \\
\text { damla) damlatılmış pamuk } \\
\text { hastaların yakasına tutturulmuştur } \\
\text { ve hastaların } 15-20 \text { dakika } \\
\text { solumaları istenmiştir. } \\
\text { Gevşeme grubunda Benson } \\
\text { gevşeme tekniği } 15-20 \text { dakika } \\
\text { uygulatılmıştır. }\end{array}$ & $\begin{array}{l}\text {-Kısa Yorgunluk } \\
\text { Envanteri }\end{array}$ & $\begin{array}{l}\text { Uygulamadan sonra } \\
\text { iki müdahale ve } \\
\text { kontrol grubu } \\
\text { arasındaki yorgunluk } \\
\text { puanları arasında fark } \\
\text { olduğu; aromaterapi } \\
\text { inhalasyon grubunda } \\
\text { ise BGT grubuna göre } \\
\text { yorgunluğun } \\
\text { istatistiksel olarak } \\
\text { daha anlamlı azalma } \\
\text { gösterdiği rapor } \\
\text { edilmiştir. }\end{array}$ \\
\hline 16 & $\begin{array}{l}\text { Misır, } \\
2019\end{array}$ & Meawad ve ark. & BGT & $\begin{array}{l}\text { Tek gruplu } \\
\text { yarı-deneysel } \\
\text { ön-test son } \\
\text { test } \\
\text { karşılaştırmalı } \\
\text { çalışma }\end{array}$ & $\begin{array}{l}92 \text { HD hastası } \\
\text { Kadın: } 28 \\
\text { Erkek: } 64 \\
\text { Yaş ortalaması: } 66\end{array}$ & $\begin{array}{l}\text { Katılımcılara } 8 \text { hafta günde } 2 \text { kez } 20 \\
\text { dk. süreyle Benson gevşeme tekniği } \\
\text { uygulatılımıştır. }\end{array}$ & $\begin{array}{l}\text {-Mini-Mental Durum } \\
\text { Ölçeği } \\
\text {-Hastane Depresyon- } \\
\text { Anksiyete Skalası } \\
\text {-Pittsburgh Uyku } \\
\text { Kalite İndeksi }\end{array}$ & $\begin{array}{l}\text { Hastaların anksiyete } \\
\text { ve depresyon } \\
\text { puanlarında önemli } \\
\text { oranda azalma ve } \\
\text { uyku kalitelerinde } \\
\text { iyileşme olduğu } \\
\text { belirtilmiştir. }\end{array}$ \\
\hline 17 & $\begin{array}{l}\text { İran, } \\
2013\end{array}$ & $\begin{array}{l}\text { Hasankhani ve } \\
\text { ark. }\end{array}$ & $\begin{array}{l}\text { Klasik İsveç Masajı/ Sırt, } \\
\text { boyun, omuz, kollar ve } \\
\text { eller }\end{array}$ & RKÇ & $60 \mathrm{HD}$ hastası & $\begin{array}{l}\text { Müdahale grubundaki hastalara } 4 \\
\text { hafta boyunca haftada } 3 \text { kez 15:00- } \\
\text { 19:00 saatlerinde HD sırasında 10 } \\
\text { dakika yavaş vuruş tekniğiyle sırt } \\
\text { masajı yapılmışır. } \\
\text { Masaj sırt, boyun, omuz, kollar ve } \\
\text { eller şeklinde sırayla bölgeler } \\
\text { öfloraj, petrisaj, vibrasyon ve } \\
\text { friksiyon teknikleri kullanılarak } \\
\text { uygulanmıştır. }\end{array}$ & $\begin{array}{l}\text {-Piper Yorgunluk } \\
\text { Ölçeği }\end{array}$ & $\begin{array}{l}\text { Uygulamadan sonra } \\
\text { hastaların yorgunluk } \\
\text { puanlarında } \\
\text { istatistiksel olarak } \\
\text { anlamlı bir azalma } \\
\text { olduğu bildirilmiştir. }\end{array}$ \\
\hline 18 & $\begin{array}{l}\text { İran, } \\
2016\end{array}$ & $\begin{array}{l}\text { Mortazavi ve } \\
\text { ark }\end{array}$ & $\begin{array}{l}\text { Klasik İsveç Masajı/ Sırt } \\
\text { Bölgesi }\end{array}$ & RKÇ & $41 \mathrm{HD}$ hastası & $\begin{array}{l}\text { Müdahale grubuna } 4 \text { hafta boyunca } \\
\text { haftada } 3 \text { kez ( } 12 \text { seans) } 20 \mathrm{dk} \text {. } \\
\text { Öfloraj tekniği ile masaj } \\
\text { uygulanmıştır. }\end{array}$ & $\begin{array}{l}\text {-Hemodiyaliz Stres } \\
\text { Ölçeği }\end{array}$ & $\begin{array}{l}\text { Uygulamadan sonra } \\
\text { hastaların fizyolojik } \\
\text { stres düzeylerinde } \\
\text { istatistiksel olarak } \\
\text { anlamlı azalma } \\
\text { olduğu bildirilmiştir. }\end{array}$ \\
\hline 19 & $\begin{array}{l}\mathrm{ABD} \\
2016\end{array}$ & $\begin{array}{l}\text { Mastnardo ve } \\
\text { ark. }\end{array}$ & $\begin{array}{l}\text { Klasik İsveç Masajı/ Her } \\
\text { iki bacak }\end{array}$ & RKÇ & $\begin{array}{l}26 \text { HD hastası } \\
\text { Kadın: } 14 \\
\text { Erkek: } 12 \\
\text { Yaş ortalaması: } 53\end{array}$ & $\begin{array}{l}\text { Müdahale grubundaki hastalara } 2 \\
\text { hafta boyunca katılığı her HD } \\
\text { tedavisi sırasında masaj terapistleri } \\
\text { tarafından } 20 \text { dakika friksiyon } \\
\text { tekniği ile masaj uygulanmıştır. }\end{array}$ & $\begin{array}{l}\text { - Böbrek Hastalığı } \\
\text { Yaşam Kalitesi Kısa } \\
\text { Formu (KDQOL-SF) }\end{array}$ & $\begin{array}{l}\text { Evde ve HD sırasında } \\
\text { krampların müdahale } \\
\text { grubunda kontrol } \\
\text { grubuna göre azaldığı } \\
\text { belirlenmiştir. } \\
\end{array}$ \\
\hline
\end{tabular}


Tablo 3. Sistematik Derlemeye Dahil Edilen Araştırmaların Özellikleri ( $n=31)$ (devamı)

\begin{tabular}{|c|c|c|c|c|c|c|c|c|}
\hline 20 & $\begin{array}{l}\text { Türkiye, } \\
2016\end{array}$ & Ünal ve ark & $\begin{array}{l}\text { Klasik İsveç Masajı/ Sırt } \\
\text { bölgesi ve Refleksoloji/ Her } \\
\text { iki ayak }\end{array}$ & RKÇ & $\begin{array}{l}105 \text { HD hastası } \\
\text { Kadın: } 35 \\
\text { Erkek: } 70 \\
\text { Yaş ortalaması: } 52\end{array}$ & $\begin{array}{l}\text { Her iki müdahale grubuna da } 4 \\
\text { hafta süreyle haftada iki gün } \\
\text { (toplam } 8 \text { seans) HD'ye girmeden } \\
\text { önce bulundukları gruba göre } \\
\text { refleksoloji ya da sırt masajı } \\
\text { uygulamaları yapılmıştır. }\end{array}$ & $\begin{array}{l}\text {-Görsel Analog } \\
\text { Yorgunluk Ölçeği } \\
\text {-Pittsburg Uyku } \\
\text { Kalitesi İndeksi }\end{array}$ & $\begin{array}{l}\text { Hastaların Görsel } \\
\text { Analog Yorgunluk } \\
\text { Ölçeği ve Pittsburg } \\
\text { Uyku Kalitesi İndeksi } \\
\text { ön test ve son test } \\
\text { puan ortalamaları } \\
\text { arasındaki farkın } \\
\text { istatistiksel olarak } \\
\text { anlamlı olduğu } \\
\text { bulunmuştur. }\end{array}$ \\
\hline 21 & $\begin{array}{l}\text { İran, } \\
2018\end{array}$ & $\begin{array}{l}\text { Ahmadidarrehsi } \\
\text { ma ve ark }\end{array}$ & $\begin{array}{l}\text { Klasik İsveç Masajı/Sırt } \\
\text { bölgesi veya her iki ayak }\end{array}$ & $\begin{array}{l}\text { Tek gruplu } \\
\text { yarı- } \\
\text { deneysel } \\
\text { ön-test son } \\
\text { test } \\
\text { karşılaştırm } \\
\text { alı çalışma }\end{array}$ & 52 HD hastası & $\begin{array}{l}\text { Üç hafta boyunca, haftada iki kez } \\
\text { (toplamda } 6 \text { seans) olmak üzere } \\
\text { ayak masajı veya yüzeyel sırt masajı } \\
\text { yapılmıştır. }\end{array}$ & -Yorgunluk Skalası & $\begin{array}{l}\text { Refleksoloji grubunun } \\
\text { yüzeyel sırt masajı } \\
\text { grubuna göre } \\
\text { yorgunluk puanlarının } \\
\text { anlamlı olarak } \\
\text { azaldığı bildirilmiştir. }\end{array}$ \\
\hline 22 & $\begin{array}{l}\text { Kanada, } \\
2017\end{array}$ & Thomas ve ark. & Meditasyon & RKÇ & $41 \mathrm{HD}$ hastası & $\begin{array}{l}\text { Müdahale grubuna, HD sırasında } \\
\text { haftada üç kez 10-15 dakika süren } 8 \\
\text { hafta bireysel hasta başı } \\
\text { meditasyon müdahalesi } \\
\text { uygulanmıştır. }\end{array}$ & $\begin{array}{l}\text {-Yaygın Anksiyete } \\
\text { Bozukluğu-7 }\end{array}$ & $\begin{array}{l}\text { Hastaların anksiyete } \\
\text { ve depresyon } \\
\text { puanlarında } \\
\text { uygulama öncesi ve } \\
\text { sonrası test puanları } \\
\text { arasında istatistiksel } \\
\text { olarak önemli bir fark } \\
\text { olmadığı belirtilmiştir. }\end{array}$ \\
\hline 23 & $\begin{array}{l}\text { İran, } \\
2014\end{array}$ & $\begin{array}{l}\text { Bassirimoghada } \\
\mathrm{m} \text { ve ark. }\end{array}$ & PGE & RKÇ & $90 \mathrm{HD}$ hastası & $\begin{array}{l}\text { Müdahale grubuna } 6 \text { hafta boyunca } \\
\text { haftada } 3 \text { kez progresif gevşeme } \\
\text { egzersizi yaptırılmıştır. }\end{array}$ & $\begin{array}{l}\text {-Yorgunluk Şiddeti } \\
\text { Ölçeği }\end{array}$ & $\begin{array}{l}\text { Müdahaleden sonra } \\
\text { iki grup arasında } \\
\text { yorgunluk düzeyinde } \\
\text { anlamlı bir fark } \\
\text { olduğu belirlenmiştir. }\end{array}$ \\
\hline
\end{tabular}


Tablo 3. Sistematik Derlemeye Dahil Edilen Araştırmaların Özellikleri ( $n=31)$ (devamı)

\begin{tabular}{|c|c|c|c|c|c|c|c|c|}
\hline 24 & $\begin{array}{l}\text { İran, } \\
2016\end{array}$ & Amini ve ark. & PGE veya aerobik egzersiz & RKÇ & 100 HD hastası & $\begin{array}{l}\text { Müdahale grubundaki hastalara } 60 \\
\text { gün boyunca her gün progresif } \\
\text { gevşeme egzersizi ya da aerobik } \\
\text { egzersiz yaptırılmışır. }\end{array}$ & $\begin{array}{l}\text {-Piper Yorgunluk } \\
\text { Ölçeği } \\
\text {-Rhoten Yorgunluk } \\
\text { Ölçeği } \\
\text {-Beck Anksiyete } \\
\text { Ölçeği }\end{array}$ & $\begin{array}{l}\text { Uygulama sonrası } \\
\text { progresif gevşeme } \\
\text { egzersizi ve aerobik } \\
\text { egzersizin Beck } \\
\text { Anksiyete Ölçek } \\
\text { puanlarını önemli } \\
\text { ölçüde azalttığı; uyku } \\
\text { kalitesini arttırdığı } \\
\text { bildirilmiştir. } \\
\text { Progresif gevşeme } \\
\text { egzersizinin aerobik } \\
\text { egzersizine göre daha } \\
\text { etkili bulunduğu } \\
\text { bildirilmiştir. }\end{array}$ \\
\hline 25 & $\begin{array}{l}\text { Türkiye, } \\
2020\end{array}$ & Serin ve ark. & PGE & RKÇ & 96 HD hastası & $\begin{array}{l}6 \text { hafta boyunca haftada } 2 \text { kez } \\
\text { araştırmacı tarafından diyaliz } \\
\text { merkezinde sessiz bir odada ve } \\
\text { evde günde } 1 \text { kez progresif gevşeme } \\
\text { egzersizi ( } 30-40 \text { dk.) uygulatılıştır. }\end{array}$ & $\begin{array}{l}\text {-Piper Yorgunluk } \\
\text { Ölçeği } \\
\text {-Görsel Analog Skala } \\
\text { (VAS) } \\
\text {-SF-36 Yaşam Kalitesi } \\
\text { Ölçeği }\end{array}$ & $\begin{array}{l}\text { Progresif gevşeme } \\
\text { egzersizinden sonra } \\
\text { müdahale grubunun } \\
\text { yorgunluk ve ağrı } \\
\text { puanlarının azaldığı; } \\
\text { yaşam kalitesi } \\
\text { puanının ise artı̆ı̆ı } \\
\text { rapor edilmiştir. }\end{array}$ \\
\hline 26 & $\begin{array}{l}\text { Türkiye, } \\
2013\end{array}$ & Özdemir ve ark. & Refleksoloji/ Her iki ayak & RKÇ & $\begin{array}{l}80 \text { HD hastası } \\
\text { Kadın: } 50 \\
\text { Erkek: } 30 \\
\text { Yaş ortalaması: } 48\end{array}$ & $\begin{array}{l}\text { Ayak refleksolojisi, sertifikalı } \\
\text { araştırmacı tarafından her ayak için } \\
15 \mathrm{dk} \text {. olmak üzere toplam } 30 \mathrm{dk} \text {. } \\
\text { boyunca }\end{array}$ & $\begin{array}{l}\text {-Piper Yorgunluk } \\
\text { Ölçeği } \\
\text {-Görsel Analog } \\
\text { Skala (VAS) }\end{array}$ & $\begin{array}{l}\text { Uygulama sonrasında } \\
\text { yorgunluk, kramp ve } \\
\text { ağrı puanlarında } \\
\text { istatistiksel olarak } \\
\text { anlamlı azalma } \\
\text { bildirilmiştir. }\end{array}$ \\
\hline 27 & $\begin{array}{l}\text { İran, } \\
2014\end{array}$ & $\begin{array}{l}\text { Aliasgharpour } \\
\text { ve ark. }\end{array}$ & Refleksoloji/ Her iki ayak & RKÇ & 90 HD hastası & Ayak ve el refleksolojisi & -Yorgunluk Anketi & $\begin{array}{l}\text { Uygulamaların, } \\
\text { kontrol ve müdahale } \\
\text { grupları arasında } 3 . \\
\text { hafta başlangıcından } \\
\text { önce ve sonra } \\
\text { istatistiksel olarak } \\
\text { anlamlı bir fark } \\
\text { oluşturmadığı, ancak } \\
\text { 5. hafta, kontrol ve } \\
\text { müdahale grupları } \\
\text { arasında anlamlı bir } \\
\text { farklılık gözlendiği } \\
\text { bildirilmiştir. }\end{array}$ \\
\hline
\end{tabular}


Tablo 3. Sistematik Derlemeye Dahil Edilen Araştırmaların Özellikleri ( $n=31)$ (devamı)

\begin{tabular}{|c|c|c|c|c|c|c|c|c|}
\hline 28 & $\begin{array}{l}\text { İran, } \\
2016\end{array}$ & $\begin{array}{l}\text { Roshanravan ve } \\
\text { ark. }\end{array}$ & Refleksoloji/ Her iki ayak & RKÇ & $78 \mathrm{HD}$ hastası & $\begin{array}{l}\text { Müdahale grubundaki hastalara ayak } \\
\text { refleksolojisi yapılmıştır. Plasebo } \\
\text { grubundaki hastalara ise ayağın belirli } \\
\text { kısımlarına baskı uygulamadan basit } \\
\text { ayak masajı uygulanmıştır. }\end{array}$ & $\begin{array}{l}\text {-Piper Yorgunluk } \\
\text { Ölçeği }\end{array}$ & $\begin{array}{l}\text { Uygulama sonrasında } \\
\text { yorgunluk puanında } \\
\text { istatistiksel olarak } \\
\text { anlamlı azalma } \\
\text { olduğu bildirilmiştir. }\end{array}$ \\
\hline 29 & $\begin{array}{l}\text { İran, } \\
2018\end{array}$ & $\begin{array}{l}\text { Izadpanah ve } \\
\text { ark. }\end{array}$ & Refleksoloji/ Her iki ayak & RKÇ & $70 \mathrm{HD}$ hastası & $\begin{array}{l}\text { Müdahale grubundaki hastalara ayak } \\
\text { refleksolojisi, kontrol grubundaki } \\
\text { hastalara ise sadece rutin bakım } \\
\text { verilmiştir. }\end{array}$ & $\begin{array}{l}\text {-Yorgunluk Şiddeti } \\
\text { Ölçeği }\end{array}$ & $\begin{array}{l}\text { Refleksoloji grubu } \\
\text { yorgunluk puanları } \\
\text { uygulamadan hemen } \\
\text { sonra ve bir hafta } \\
\text { sonra yapılan } \\
\text { ölçümlerde anlamlı } \\
\text { bir fark göstermiştir, } \\
\text { ancak müdahaleden } \\
\text { hemen sonra ve bir } \\
\text { hafta sonra alınan } \\
\text { puanlar arasında } \\
\text { anlamlı bir fark } \\
\text { olmadığı belirtilmiştir }\end{array}$ \\
\hline 30 & $\begin{array}{l}\text { İran, } \\
2019\end{array}$ & $\begin{array}{l}\text { Emamverdi ve } \\
\text { ark. }\end{array}$ & $\begin{array}{l}\text { Akupresür/Shen Men } \\
\text { noktası ve Refleksoloji/ } \\
\text { Her iki ayak }\end{array}$ & RKÇ & $90 \mathrm{HD}$ hastası & $\begin{array}{l}\text { Toplamda } 12 \text { seans; akupresür } \\
\text { grubundaki hastalara Shen Men } \\
\text { noktasına masaj, refleksoloji } \\
\text { grubundaki hastalara ise ayak } \\
\text { refleksolojisi yapılmıştır. }\end{array}$ & $\begin{array}{l}\text {-Pittsburgh Uyku } \\
\text { Kalitesi Ölçeği }\end{array}$ & $\begin{array}{l}\text { Uygulamalardan } \\
\text { sonra, refleksoloji } \\
\text { grubunda ve } \\
\text { akupunktur grubunda } \\
\text { uyku puanlarında } \\
\text { kontrol grubuna göre } \\
\text { anlamlı iyileşme } \\
\text { görülürken; iki } \\
\text { müdahale grubu } \\
\text { arasında anlamlı bir } \\
\text { fark görülmediği } \\
\text { bildirilmiştir. }\end{array}$ \\
\hline 31 & $\begin{array}{l}\text { İran, } \\
2019\end{array}$ & Naseri ve ark. & Refleksoloji/Her iki ayak & RKÇ & $\begin{array}{l}72 \text { HD hastası } \\
\text { Kadın: } 36 \\
\text { Erkek: } 36 \\
\text { Yaş ortalaması: } 62\end{array}$ & $\begin{array}{l}\text { Her iki gruptaki hastalar, HD seansının } \\
\text { başlamasından hemen sonra nefrolog } \\
\text { tarafından reçete edilen antiemetik } \\
\text { ilaç ( } 4 \mathrm{mg} \text { Ondansetron) almışıtır. } \\
\text { Refleksoloji, solar pleksustaki mide } \\
\text { bulantısı alanında ve ayak } \\
\text { tabanlarında HD seansının } \\
\text { başlamasından } 1 \text { saat sonra } 12 \text { gün } \\
\text { boyunca günde bir kez (seans başına } \\
30 \text { dakika) yavaş hızda, düzenli } \\
\text { ritimde ve } 1-3 \text { mm derinliklerde } \\
\text { yapılmıştır. }\end{array}$ & $\begin{array}{l}\text {-Görsel Analog } \\
\text { Skala (VAS) }\end{array}$ & $\begin{array}{l}\text { Uygulama sonrası 3., } \\
6 ., 9 . \text { ve } 12 \text {. günlerde } \\
\text { bulantı şiddetinin } \\
\text { kontrol grubuna göre } \\
\text { anlamlı derecede } \\
\text { düşük olduğu } \\
\text { bildirilmiştir. }\end{array}$ \\
\hline
\end{tabular}




\section{BULGULAR}

Tamamlayıcı ve İntegratif Yaklaşımlar ve Veri Toplama Prosedürleri

Bu sistematik derleme kapsamında 31 araştırma makalesi incelenmiştir. Araştırmalar akupunktur $(n=3)$, aromaterapi masajı $(n=4), \operatorname{BGT}(n=9)$, klasik İsveç masajı $(n=5)$, meditasyon $(n=1)$, PGE $(n=3)$, refleksoloji $(n=6)$ gibi farklı yedi tamamlayıcı ve integratif yaklaşımın $H D$ hastalarında görülen semptomlara etkilerini incelemişlerdir. Bu sistematik derlemede, araştırmaların HD hastalarında sıklıkla görülen yorgunluk ( $n=15)$, sıkıntı, stres, anksiyete ve depresyon $(n=9)$, uyku sorunları $(n=5)$, ağrı $(n=5)$, kas krampları ( $n=2)$, kaşıntı $(n=2)$, hipotansiyon $(n=1)$ ve bulantı $(n=1)$ gibi semptomların hafifletilmesine yönelik zihin-beden temelli ( $n=13)$, dokunma temelli (15) ve enerji temelli $(n=3)$ tamamlayıcı ve integratif yaklaşımların etkilerini incelediği, bu uygulamaların çoğunluğunda ( $n=30, \% 96.8)$ HD hastalarının semptom şiddetlerinin anlamlı düzeyde azaldığı ortaya çıkarılmıştır $(\mathrm{p}<0.05)$. Ayrıca, araştırmalarda hastaların \%42'sinin kadın olduğu ve yaş aralığının 23 ile 66 yıl arasında değiştiği görülmüştür. Çalışma kapsamında tamamlayıcı ve integratif yaklaşımlar ve etkilerine yönelik bulgular alfabetik sırayla ele alınmıştır.

\section{Akupunktur}

Hadadian ve ark.'nın Trans Kutanöz Elektriksel Akupunktur Noktası Stimülasyonunun (TEAS) HD hastalarında yorgunluğa etkilerini değerlendirdikleri çalışmada hastalar TEAS $(n=28)$ ve plasebo $(n=28)$ olarak ayrılmıştır. Tüm hastaların altı akupunktur noktasına, 5 hafta boyunca haftada 2-3 kez HD seansının başlamasından 2 saat sonra bilateral 5 dakika TEAS uygulanmıştır. Plasebo grubunda TEAS uygulaması, gerçek akupunktur noktalarının yakınındaki noktalara yapılmıştır. Veriler, uygulamanın başında ve sonunda Kısa Yorgunluk Envanteri ile toplanmıştır ve TEAS grubunda yorgunluğun anlamlı şekilde azaldığı görülmüştür ${ }^{16}$.

Akça ve Taşcı akupresör ve TEAS'ın üremik kaşıntıya etkinliğini araştırdıkları çalışmalarında, 75 HD hastası akupresör, TEAS ve kontrol gruplarına atanmıştır. Akupresör ve TEAS grubundakiler 4 hafta boyunca toplam 12 seans kolda bulunan kalın bağırsak (LI-11) akupunktur noktalarına akupresör veya TEAS tedavileri uygulanmıştır. Veriler, çalışmanın başında ve sonunda Görsel Analog Skala (VAS) ile hastaların kaşıntı şiddetinin belirlenmesiyle toplanmıştır. Akupresör ve TEAS gruplarındaki hastaların, kontrol grubuna göre kaşıntı azaldığı, akupresör ve TEAS grupları arasında ise istatistiksel açıdan bir fark olmadığı bildirilmiştir ${ }^{17}$.

Tsai ve ark. HD hastalarında gelişen intradiyalitik hipotansiyona yönelik bitkisel akupunktur noktası (HAT) tedavisinin etkinliğini değerlendirmişlerdir. Katılımcılar ( $n=27)$, HAT veya plasebo grubuna atanmıştır. Tedavi, 4 hafta boyunca haftada 3 kez her HD seansında 4 saat uygulanmıştır. HAT ve plasebo yamaları 3 akupunktur noktasına yerleştirilmiş ve üzeri gazlı bez ile kapatılmıştır. Plasebo HAT yamaları kahverengi kilden yapılmış fakat gerçek HAT ile aynı görünüşte hazırlanmıştır. Yamalar, HD seansından $10 \mathrm{dk}$. önce uygulanmış ve HD seans sonunda çıkarılmıştır. Etrafındaki deri; kızarıklık, şişlik, hassasiyet yönünden kontrol edilmiştir. Kan basıncı, her HD seansında diyalizden önce, HD sırasında her 30 dakikada bir ve diyalizden sonra ölçülmüştür. Yorgunluk, VAS ile HD bittikten sonra ölçülmüştür. Müdahalenin bitiminden 4 hafta sonra araştırmacılar katılımcıları tekrar değerlendirmiştir. Sonuçta, HAT grubundaki hastaların plasebo grubuna göre anlamlı düzeyde daha az sıklıkta hipotansiyon yaşadığı, yorgunluğun hafiflediği ve diyaliz sonrası yorgunluktan kurtulma süresinin daha kısa olduğu rapor edilmiştir ${ }^{18}$.

\section{Aromaterapi Masajı}

Shahgholian ve ark. kaşıntısı olan 20 HD hastasıyla yürüttükleri çalışmada, 2 hafta boyunca, toplam 6 seans, $\% 5$ konsantrasyonda 3-5 ml lavanta, nane ve çay ağacı yağları ile fistül bulunmayan kola $7 \mathrm{dk}$. el masajı yapmışlardır. Numerik kaşıntı ölçeği müdahale öncesi ve sonrasında uygulanmış ve kaşıntı puanlarının ortalaması arasında anlamlı bir fark olduğu bildirilmiştir ${ }^{19}$.

Biçer ve ark. deneysel çalışmasında baş ağrısı görülen $25 \mathrm{HD}$ hastasına, 3 hafta boyunca haftada 3 gün, HD seanslarının ilk saatinde $10 \mathrm{dk}$. yüz bölgesine aromaterapi masajı yapmışlardır. Hastalarla yapılan ilk görüşmede ve 3 . haftanın sonunda VAS ile veriler toplanmıştır ve hastaların ağrı puanlarının anlamlı düzeyde azaldığı belirtilmiştir ${ }^{20}$.

Arslan ve Arslan deneysel araştırmasında müdahale $(n=22)$ grubundaki hastalara sertifikası olan araştırmacılar tarafından her bir el için $5 \mathrm{dk}$. süreyle 12 seans $\% 2$ lavanta yağı ve tatlı badem yağı içeren karışımla öfloraj tekniğiyle aromaterapi masajı uygulanmıştır. Araştırmacılar, hastalara araştırmanın başında ve sonunda sıkıntı ve uyku kalitesini belirleyen ölçekleri uygulamışlardır. Müdahale grubunda kontrol grubuna göre sıkıntı ve uyku kalitesi puan ortalamalarında istatistiksel olarak anlamlı bir azalma olduğu bildirilmiştir ${ }^{21}$.

Varaei ve ark. inhalasyon ve masaj aromaterapiyle uygulanan lavanta ve tatlı portakal yağı karışımının yorgunluk üzerine etkilerini karşılaştırmışlardır. Hastalar $(n=96)$, inhalasyon aromaterapi, masaj aromaterapi ve kontrol gruplarına ayrılmıştır. Uygulamanın başlangıcında, 8 . hafta ve 16. haftada hastaların yorgunluk seviyeleri Rhoten Yorgunluk Ölçeği kullanılarak değerlendirilmiştir. Verilerin analiziyle, iki müdahale grubundaki yorgunluğun kontrol grubuna göre anlamlı düzeyde azaldığı, ancak aromaterapi masajının yorgunluk üzerindeki etkilerinin inhalasyon aromaterapisinin etkilerinden daha güçlü olduğu bildirilmiştir22.

\section{Benson Gevşeme Tekniği}

Mahdavi ve ark. HD tedavisi alan 80 hasta ile yaptıkları çalışmada BGT'nin stres, anksiyete ve depresyon üzerine etkilerini; Gorji ve ark. 80 hasta ile yürüttükleri araştırmada ise BGT'nin HD hastalarında görülen ağrı, stres ve anksiyeteye etkilerini incelemişlerdir. Çalışmalarda, hastalara BGT uygulama CD'si verilerek 4 hafta boyunca günde 2 kez $15 \mathrm{dk}$. süreyle egzersizi evde/diyaliz merkezinde uygulamaları istenmiştir. Veriler, iki çalışmada da müdahale öncesi ve sonrasında Depresyon Anksiyete Stres Ölçeği-21 ile toplanmıştır. Mahdavi'nin çalışmasında, müdahale 
grubunda stres ve anksiyete düzeyleri arasında anlamlı farklar olduğu; depresyon puan ortalamaları arasındaki farkın ise anlamlı olmadığı; Gorji'nin çalışmasında ise müdahale grubunda ağrı algısı, stres ve anksiyete düzeyleri arasında anlamlı azalma olduğu raporlanmıştı ${ }^{23,24}$.

Rambod ve ark. yaptıkları iki randomize kontrollü çalışmaın ilkinde ( $n=86)$ BGT'nin uyku kalitesine, ikinci çalışmada $(n=86)$ ise ağrı ve yaşam kalitesi üzerine etkileri değerlendirilmiştir. Müdahale grubundaki hastalar, aldıkları BGT eğitimi sonrasında evde CD kaydından 8 hafta boyunca her gün günde iki kez 20 dakika BGT'yi uygulamışlardır. Araştırmaların sonuçlarında BGT'nin ağrıyı önemli ölçüde hafiflettiği, uyku kalitesi ve yaşam kalitesini iyileştirdiği bildirilmiştir ${ }^{25,26}$.

Koushan ve ark. çalışmasında müdahale grubuna $(n=33) 4$ hafta boyunca günde $2 \mathrm{kez} 15 \mathrm{dk}$. BGT, kontrol grubuna $(n=32)$ ise müdahalede bulunulmamıştır. Veriler müdahaleden önce, 2 ve 4 hafta sonra Kısa Yorgunluk Envanteriyle elde edilmiş ve müdahale grubunda yorgunluk puanı ortalamasının anlamlı düzeyde azaldığı belirtilmiştir ${ }^{27}$. Heshmatifar ve ark. çalışmasında HD hastaları müdahale $(n=33)$ ve kontrol gruplarına $(n=32)$ atanmıştır. Müdahale grubundaki hastalara 4 hafta boyunca günde 2 kez HD seansına geldiklerinde, grup halinde $20 \mathrm{dk}$. BGT uygulamışlardır. Ayrıca, BGT uygulama CD'si hastalara verilmiş ve evde de uygulamaları istenmiştir. Beck Depresyon Envanteri, müdahaleden önce ve sonra tüm hastalar tarafından doldurulmuş ve çalışma sonunda depresyon puanlarında anlamlı düzeyde azalma olduğu belirlenmiştir ${ }^{28}$.

Otaghi ve ark. çalışmasında müdahale grubundaki hastalara ( $n=35) 4$ hafta günde 2 kez $15 \mathrm{dk}$. BGT uygulanmıştır. Depresyon Anksiyete Stres Ölçeği-21 ile müdahaleden hemen önce, müdahaleden bir, iki ve üç ay sonra araştırmacılar tarafından veriler toplanmıştır. Uygulamadan sonra hastaların depresyon düzeylerinde gruplar arasında fark yokken; stres ve anksiyete düzeylerinde anlamlı düzeyde azalma olduğu bildirilmiştir ${ }^{29}$.

Hassanzadeh ve ark. araştırmasında 105 HD hastası rastgele üç gruba (gevşeme, aromaterapi ve kontrol) ayrılmıştır. Dört hafta boyunca günde iki kez, aromaterapi grubunda \%5 lavanta yağı (2 damla) damlatılmış pamuk hastaların yakasına tutturulmuştur ve hastaların $15-20 \mathrm{dk}$. solumaları istenmiş, gevşeme grubunda ise BGT diyaliz servisinde ve evde 15-20 dk. uygulatılmıştır. Uygulamalardan sonra iki müdahale ve kontrol grubu arasındaki yorgunluk puanları arasında fark olduğu; aromaterapi inhalasyon grubunda ise BGT grubuna göre yorgunluğun anlamlı düzeyde azaldığı gösterilmiştir ${ }^{30}$.

Meawad ve ark. 60 yaş ve üstü HD hastalarıyla tek gruplu ( $n=92$ ) olarak gerçekleştirdiği, yarı-deneysel araştırmada, 8 hafta günde 2 kez $20 \mathrm{dk}$. süreyle BGT uygulatılmıştır. Veriler, Mini-Mental Durum Ölçeği, Hastane Depresyon-Anksiyete Skalası ve Pittsburgh Uyku Kalite İndeksiyle toplanmış ve sonuçlar pre-test/post-test şeklinde karşılaştırılmıştır. Sonuçta, hastaların anksiyete ve depresyon puanlarında anlamlı düzeyde azalma ve uyku kalitelerinde iyileşme olduğu belirtilmiştir ${ }^{31}$.

\section{Klasik İsveç Masajı}

Hasankhani ve ark. deneysel çalışmasında müdahale grubundaki hastalara $(n=30) 4$ hafta boyunca haftada $3 \mathrm{kez}$ diyaliz sırasında $10 \mathrm{dk}$. sırt, boyun, omuz, kollar ve ellere sırayla öfloraj, petrisaj, vibrasyon ve friksiyon teknikleri kullanılarak yüzeyel sırt masajı yapılmıştır. Kontrol grubuna $(n=30)$ müdahalede bulunulmamıştır. Çalışmanın başında, 15. ve 30. gününde her iki gruba Piper Yorgunluk Ölçeği (PYÖ) uygulanmıştır ve yorgunluk puanları karşılaştırılmıştır. Sonuçta, müdahale grubundaki hastaların yorgunluk puanlarında istatistiksel olarak anlamlı bir azalma olduğu bildirilmiştir ${ }^{32}$.

Mortazavi ve ark. çalışmalarında müdahale grubuna $(n=20)$ 4 hafta boyunca haftada $3 \mathrm{kez} 20 \mathrm{dk}$. masaj uygulanmış, kontrol grubu $(n=21)$ rutin bakım almıştır. Her iki grupta da müdahale öncesi ve sırasında Hemodiyaliz Stres Ölçeği ile stres puanları belirlenmiştir. Uygulamadan sonra hastaların fizyolojik stres düzeylerinde istatistiksel olarak anlamlı bir azalma olduğu bildirilmiştir ${ }^{33}$.

Mastnardo ve ark. çalışmasında müdahale $(n=11)$ grubundaki hastalara 2 hafta boyunca katıldığı her HD tedavisi sırasında eğitimli masaj terapistleri tarafından diz dahil olmak üzere bacaklara ve ayaklara friksiyon tekniğiyle $20 \mathrm{dk}$. masaj uygulanmıs ve kontrol $(n=15)$ grubundaki hastalar diyaliz merkezi personeli tarafından verilen rutin bakımlarını almışlardır. Diyaliz esnasında, diyaliz tedavileri arasında (evde) ve uygulama sonunda hastaların önceki iki hafta içinde yaşadıkları kramp sıklığı, yeri, süresi ve şiddeti belirlenmiştir. Sonuçta; müdahale grubunda evde ve diyaliz sırasında krampların kontrol grubuna göre azaldığı belirlenmiştir ${ }^{34}$.

Ünal ve Akpınar 105 HD hastasıyla (ayak refleksoloji=35, sırt masajı=35, kontrol=35) tamamladıkları çalışmada, ayak refleksolojisi ve sırt masajının yorgunluk ve uyku kalitesine etkilerini karşılaştırmışlardır. Dört hafta süreyle haftada iki gün HD'e girmeden önce; ayak refleksoloji grubundaki hastalara $15 \mathrm{dk}$. refleksoloji, sırt masajı grubundaki hastalara ise öfloraj, petrisaj ve friksiyon teknikleriyle $30 \mathrm{dk}$. sırt masajı uygulanmıştır. Hastaların pre-post test puan ortalamaları arasındaki fark karşılaştırılmış, yorgunluk ve uyku kalitesi ölçek puan ortalamaları arasındaki farkın istatistiksel olarak anlamlı olduğu bulunmuştur ${ }^{35}$.

Ahmadidarrehsima ve ark. yarı-deneysel araştırmasında ayak refleksolojisi ve sırt masajının HD hastalarında $(n=52)$ görülen yorgunluğa etkilerini incelemişlerdir. Üç hafta boyunca, haftada iki kez ayak masajı veya yüzeyel sırt masajı yapılmıştır. Çalışmanın sonunda, refleksoloji grubunun yüzeyel sırt masajı grubuna göre yorgunluk puanlarının anlamlı olarak azaldığı bildirilmiştir ${ }^{36}$.

\section{Meditasyon}

Thomas ve ark. pilot çalışmasında, müdahale $(n=21)$ grubundaki hastalara 8 hafta boyunca haftada 3 kez HD sırasında 10-15 dk. süren, bireysel olarak uygulanan, Farkındalığa Dayalı Meditasyon Uygulaması (beden taraması, rehberli meditasyon, sessiz meditasyon ve yumuşak kol hareketleri) yapılmıs, kontrol grubu $(n=20)$ rutin bakım almıştır. Araştırma sonunda, hastaların anksiyete ve depresyon puanlarında uygulama öncesi ve 
sonrası istatistiksel olarak önemli bir fark olmadığ belirtilmiştir ${ }^{37}$.

\section{Progresif Kas Gevşeme Egzersizi}

Bassirimoghadam ve ark. müdahale grubuna $(n=45) 6$ hafta boyunca haftada 3 kez PGE yaptırılmış, kontrol grubuna $(n=45) \quad$ herhangi bir müdahalede bulunulmamıştır. Müdahaleden sonra iki grup arasında yorgunluk düzeyinde anlamlı düzeyde bir fark olduğu belirlenmiştir ${ }^{38}$.

Amini ve ark. 100 HD hastasını PGE, aerobik egzersiz ve kontrol gruplarına atayarak, müdahale grubundaki hastalara 60 gün boyunca her gün PGE ya da aerobik egzersiz yaptırılmıştır. Uygulama sonrası PGE ve aerobik egzersiz Beck Anksiyete Ölçek puanlarını anlamlı düzeyde azaltırken; uyku kalitesini de anlamlı düzeyde arttırmıştır. Progresif gevşeme egzersizi, Rhoten Yorgunluk Ölçek puanlarında azalma sağlarken; PYÖ puanlarını etkilememiştir. Aerobik egzersizin, Rhoten ve PYÖ puanları üzerinde etkisi anlamlı bulunmamıştır. Sonuçta, PGE'nin aerobik egzersizine göre daha etkili olduğu bildirilmiştir ${ }^{39}$.

Serin ve ark.'nın çalışmasında müdahale grubundaki hastalara $(n=48)$ uygulamanın ilk günü PGE eğitimi verilmiştir. Altı hafta boyunca haftada 2 kez araştırmacı tarafından diyaliz merkezinde sessiz bir odada ve evde Türk Psikologlar Derneği tarafından hazırlanan PGE CD'si ile günde 1 kez (30-40 dk.) PGE uygulatılması sağlanmıştır. Çalışma sonuçlarında, PGE uygulamasından sonra müdahale grubunda yorgunluk ve ağrı puanlarının azaldığı ve yaşam kalitesi puanının arttığı rapor edilmiştiı ${ }^{40}$.

\section{Refleksoloji}

Özdemir ve ark. çalışmasında $(n=80) 15$ dk. ayak refleksolojisi uygulanmıştır. Müdahale ve kontrol gruplarının verileri, PYÖ ve VAS kullanılarak ilk HD seansından 10 dakika sonra toplanmıştır. Bir hafta süreyle gerçekleştirilen 3 refleksoloji seansının ardından, üçüncü HD tedavisinden yaklaşık $10 \mathrm{dk}$. sonra müdahale ve kontrol gruplarına PYÖ ve VAS tekrar uygulanmıştır. Uygulama sonrasında müdahale grubunda yorgunluk, kramp ve ağrı puanlarında istatistiksel olarak anlamlı azalma olduğu bildirilmiştir ${ }^{41}$.

Aliasgharpour ve ark. üç gruplu randomize çalışmasında, HD hastalarında görülen yorgunluğa el ve ayak refleksolojisinin etkilerini karşılaştırmışlardır. Araştırma verileri, müdahalenin başında, 3. hafta uygulama öncesi ve sonrasında, 5. hafta uygulama öncesi ve sonrasında yorgunluğun şiddetini belirleyen bir ölçek yardımıyla toplanmıştır. Uygulamaların, kontrol ve müdahale grupları arasında 3. hafta başlangıcından önce ve sonra istatistiksel olarak anlamlı bir fark oluşturmadığı, ancak 5 . hafta, kontrol ve müdahale grupları arasında anlamlı bir farklııı gözlendiği bildirilmiştir ${ }^{42}$.

Roshanravan ve ark. HD hastalarını ( $n=78)$ müdahale, plasebo ve kontrol grubuna atamışlardır. Müdahale grubundaki hastalara ayak refleksolojisi yapılmıştır. Plasebo grubundaki hastalara ise ayağın belirli kısımlarına baskı uygulamadan basit ayak masajı uygulanmıştır. Kontrol grubundaki hastalara sadece rutin bakım verilmiştir. Yorgunluk düzeyini ölçmek için çalışmanın başında ve sonunda PYÖ kullanılmıştır. Uygulama sonrasında, müdahale grubunun yorgunluk puanında istatistiksel olarak anlamlı azalma olduğu bildirilmiştir ${ }^{43}$.

Izadpanah ve ark.'nın çalışmasında müdahale grubundaki hastalara $(n=35)$ ayak refleksolojisi, kontrol grubundaki hastalara $(n=35)$ ise sadece rutin bakım verilmiştir. Hastaların yorgunluk düzeyini ölçmek için Yorgunluk Şiddeti Ölçeği müdahaleden önce, müdahaleden hemen sonra ve bir hafta sonra olmak üzere 3 kez uygulanmıştır. Refleksoloji grubu yorgunluk puanları uygulamadan hemen sonra ve bir hafta sonra yapılan ölçümler arasında istatistiksel olarak önemli bir fark göstermiştir, ancak müdahaleden hemen sonra ve bir hafta sonra alınan puanlar arasında önemli bir fark olmadığı belirtilmiştir ${ }^{44}$.

Emamverdi ve ark. klinik araştırmasında, HD hastaları rastgele akupresör $(n=30)$, refleksoloji $(n=30)$ ve kontrol $(n=30)$ gruplarına ayrıımıştır. Toplamda 12 seans; akupresör grubundaki hastalara Shen Men noktasına masaj, refleksoloji grubundaki hastalara ise ayak refleksolojisi yapılmıştır. Kontrol grubundaki hastalara herhangi bir uygulama yapılmamıştır. Araştırma sonunda, müdahale grupları arasında uyku puanları açısından anlamlı bir fark olmadığı, her iki grupta kontrol grubuna oranla uyku kalitesinin anlamlı düzeyde arttığı belirlenmiştir ${ }^{45}$.

Naseri ve ark. bulantı deneyimleyen HD hastaları müdahale $(n=36)$ ve kontrol $(n=36)$ gruplarına atamışlardır. Tüm hastalar, HD seansının başladıktan sonra nefrolog tarafından reçetelenen antiemetik ilaç (4 $\mathrm{mg}$ ondansetron) almıştır. Müdahale grubundaki hastaların solar pleksustaki mide bulantısı alanında ve ayak tabanlarında HD seansının başlamasından 1 saat sonra 12 gün boyunca günde bir kez (seans başına $30 \mathrm{dk}$.) yavaş hızda, düzenli ritimde ve $1-3 \mathrm{~mm}$ derinliklerde sertifika sahibi uygulayıcı tarafından refleksoloji yapılmıştır. Kontrol grubuna ise basit ayak masajı uygulaması yapılmıştır. Bulantı şiddetini değerlendirmek için müdahaleden 10-15 dk. sonra ve sonrasında her gün bulantının şiddeti VAS ile değerlendirilmiştir. Uygulama sonrası 3., 6., 9. ve 12. günlerde bulantı şiddetinin kontrol grubuna göre anlamlı derecede düşük olduğu bildirilmiştir ${ }^{46}$.

\section{TARTIŞMA}

Hemodiyaliz alan hastaların yaşadıkları semptomları azaltmaya yönelik uygulanan tamamlayıcı ve integratif yaklaşımları ve etkilerini inceleyen bu sistematik derleme sonucunda, bu yaklaşımların HD ilişkili semptomları azaltmada olumlu etkiler sağladığı ortaya konmuştur. Ayrıca, müdahale prosedürlerinin aşamalarının detaylı açıklanması, sağıı profesyonellerinin semptomlarla baş etmesi için bu uygulamaları HD hastalarında nasıl kullanabilecekleri ve klinik uygulamaya aktarabilecekleri konusunda yol gösterici olmuştur.

Bu sistematik derlemeye dahil edilen araştırmalar detaylıca incelendiğinde, çalışmaların BGT, PGE ve meditasyon gibi zihin-beden temelli uygulamalar üzerinde yoğunlaştığı dikkat çekmektedir. Günlük hayatta deneyimlenen olumsuz duygular ve psikosomatik hastalıklar bireylerin kas gerginliğini artırmaktadır. Gevşeme egzersizleriyle, otonom ve santral sinir sistemi aktiviteleri azaltılarak parasempatik sinir sisteminin aktivitesi artırılmaktadır ${ }^{24}$. Parasempatik 
sinir sistemi aktivitelerindeki artışa bağlı olarak; kanda epinefrin ve norepinefrin seviyesi, hücrelerin oksijen tüketimi, kan basıncı, nabız ve serum laktik asit seviyesi azalmakta, metabolizma yavaşlamakta, endorfin salınımı artmaktadır. Bu fizyolojik olaylar sonucunda hastalarda nöromüsküler gerginlik, yorgunluk, huzursuzluk belirtileri, depresyon, anksiyete ve stres düzeyleri azalmakta, dikkat ve konsantrasyon artmakta, fiziksel ve ruhsal durumda iyileşme sağlanmaktadı ${ }^{47}$. Hemodiyaliz hastalarının semptom kontrolünü sağlamada PGE ve BGT'ye (2013 yılından bu yana) yönelik ilginin gittikçe arttığı görülmektedir. Fakat, ülkemizde BGT uygulamasının etkilerinin incelendiği herhangi bir araştırma bulunmamaktadır. $\mathrm{Bu}$ derleme kapsamındaki araştırmalarda uygulama süresinin çoğunda 4 hafta olduğu görülmektedir. Herbert Benson tarafından tanımlanan BGT, hastanın kendisinin gevşeme derecesini kontrol edebildiği ve yorgunluk, uyku sorunları, anksiyete ve depresyon gibi semptomlarda iyileşme sağlayan zihin-beden temelli uygulamalar arasında öne çıkmaya devam etmektedir. Postoperatif ağrı, romatoid artrit, kalp hastalığı olan bireylerde BGT'nin etkilerinin incelendiği çalışmalarda da sonuçlar benzerlik göstermekte ve bu hastalarda semptom yönetiminde önemli gelişme sağlanabilmektedir ${ }^{48,49}$. Buradan hareketle, HD hastalarının semptom yönetiminde etkili olan ve hastaların kolayca uygulayabildiği BGT'ye yönelik araştırmaların sayısının arttırılması, sağlık personellerinin bu uygulama hakkında eğitim almaları önerilmektedir.

Köklü bir geçmişe sahip zihin-beden temelli uygulamalardan olan meditasyon, bireylerin sağlık algısını, refahını arttırmayı ve onları rahatsız eden düşüncelerden kurtulmayı sağlamaktadır ${ }^{48}$. Bu sistematik derleme kapsamına alınan tek meditasyon çalışmasının küçük örneklem ile yapıldığı ve sonuçlarının genelleştirilemeyeceği unutulmamalıdır. Araştırmada anksiyete-depresyon değerlendirilmiş, sonuçta HD hastalarının anksiyete-depresyon semptomlarında anlamlı bir azalma olduğu bildirilmiştir ${ }^{37}$. Meditasyona günümüzde ilgi artmasına rağmen HD hasta popülasyonu üzerinde yapılan klinik çalışmalar çok sınırlıdır. Bu nedenle, meditasyonun HD ilişkili semptom yönetiminde etkilerini inceleyen örneklemi büyük, ileri klinik çalışmalara gereksinim duyulmaktadır.

Zihin-beden temelli yaklaşımlara ek olarak, en eski tamamlayıcı ve integratif hemşirelik uygulamalarından biri olan dokunma temelli yaklaşımlardan klasik masajın HD hastalarında sık görülen ağrı, yorgunluk, anksiyete ve kan basıncı yüksekliği gibi pek çok semptomun yönetiminde olumlu etkiler sağladığı bildirilmektedir ${ }^{49}$. Literatürle uyumlu olarak, bu derleme kapsamındaki beş masaj çalışmasının da HD hastalarında ağrı, kramp, yorgunluk, stres gibi semptomları anlamlı şekilde azalttığı, uyku kalitesini arttırdığı bildirilmiştir ${ }^{32-35}$. Ayrıca, derleme kapsamında incelenen dört adet aromaterapi çalışmasında da HD hastalarının semptomlarında anlamlı iyileşmeler olduğu belirtilmiştir ${ }^{19-22}$. Sözü edilen çalışmalarda, sertifikalı araştırmacılar tarafından hastalara gerekli cilt testleri yapıldıktan sonra aromaterapi masajı uygulamışlardır. Sonuçlar doğrultusunda, klasik masaj ve aromaterapi masajının HD hastalarının yaşadıkları kaşıntı, ağıı, yorgunluk, stres ve uyku problemleri gibi semptomlar üzerinde olumlu etkilerinin olduğu ve bu alanda yapılacak yeni bilimsel çalışmalara gereksinim duyulduğu görülmektedir. Aromaterapi uygulamalarını hastanelerde yapabilecek sağlık çalışanlarının hemşireler olduğu ve hemşirelerin aromaterapiye yönelik uygulamaları geliştirmeleri, etkin stratejiler belirleyerek sağlıklı/hasta bireylerin aromaterapiyi etkin ve doğru kullanması için doğru ve yeterli danışmanlık hizmeti verebilmelerinin gerekli olduğu dikkate alınmalıdır.

Dokunma temelli uygulamalar arasında yer alan refleksoloji, iç organlara, endokrin bezlere ve vücut kısımlarına karşılık geldiği söylenen ayaklardaki belirli bölgelere başparmak ve işaret parmağı ile baskı uygulayarak gerçekleştirilmektedir ${ }^{52}$. Bu derlemeye göre, HD semptom yönetiminde refleksolojinin etkilerinin oldukça fazla çalışıldığı görülmektedir ${ }^{41-46}$. Araştırmalarda yorgunluk ve uyku sorunu semptomlarında refleksoloji sonrası anlamlı oranda azalma olduğu belirtilmiştir. Hemodiyaliz hasta popülasyonu tarafından kolay tolere edilebilen bu uygulamanın, büyük örneklem gruplarıyla HD hastaları tarafından deneyimlenen iştahsızlık, kaşıntı, ödem gibi diğer semptomlar üzerindeki etkilerinin incelendiği ileri klinik çalışmaların yapılması alana katkı sağlayabilecektir.

Son olarak, enerji temelli uygulamalardan olan akupunktur, lokal etki yaratarak doku onarımını tetiklemekte ve ağrı kontrol sistemini aktifleştirmektedir. Sempatik ve parasempatik sinirlerin uyarılmasıyla da iç organların işlevleri etkilenmektedir ${ }^{18}$. Bu derlemede ki dört akupunktur çalışmasında da HD hastalarının yorgunluk ve kaşıntı semptomlarında anlamlı azalmanın olması akupunkturun hemşirelik girişimleri içinde daha çok yer alabileceğini hemşire uygulayıcıların sayısının arttırıımasının gerekliliğini göstermektedir.

\section{SONUÇ ve ÖNERILER}

$\mathrm{Bu}$ derlemedeki araştırma sonuçları değerlendirildiğinde, doğası gereği kronik bir hastalık olan, oluşturduğu semptomlar nedeniyle hastaların yaşamlarını kısıtlayan $\mathrm{KBH}$ ve HD ilişkili semptomların yönetiminde tamamlayıcı ve integratif yaklaşımların olumlu etkileri olduğu sonucuna ulaşılmıştır. Diğer önemli sonuç ise; araştırma sürelerinin en az 4, en fazla 12 hafta ile sınılanması, müdahalenin bitiminde bu uygulamaların hastaların semptomları üzerindeki etkilerinin devam edip etmediğine yönelik izlemlerin yapılmaması ya da izlem sayılarının sınırlı olması, sıklıkla psikososyal semptomlara odaklanması, çoğunun küçük örneklem gruplarıyla gerçekleştirilmesi, körleme ve randomizasyon yöntemlerinin kullanılmaması veya açık şekilde ifade edilmemesi gibi nedenlerden dolayı kanıtların henüz yeterli seviyede olmamasıdır.

Bununla birlikte, hastaların çoğunun tamamlayıcı ve integratif yaklaşımlardan memnuniyet bildirmesi, örneklemlerde yaşanan kayıpların az olması, uygulamalara ilişkin ciddi yan etkilerin yaşanmaması ve ilgili ölçek puanlarında anlamlı değişimlerin ortaya konması da HD hastalarının bakım sürecinde bütüncül açıdan desteklenmesi için önemli bir alt yapı oluşturmaktadır. 
Tamamlayıcı ve integratif yaklaşımların, daha büyük örneklemler ile daha uzun süreli, birden fazla izlemin yapıldığı, bireysel/grup etkinlikleriyle kombine edildiği, evde de hastaların uygulamaları devam ettirebildiği ve HD ilişkili diğer semptomlara (iştahsızık, ödem, ağızda tat değişiklikleri, vb.) odaklanan ileri klinik araştırmaların tasarlanması önerilebilir. Ayrıca, araştırmalardan elde edilen sonuçların kliniğe aktarılabilmesi için, HD ile ilgilenen sağlık profesyonellerinin tamamlayıcı ve integratif tıp ile ilgili seminerlere daha fazla ilgi göstermesi, araştırma sonuçlarını yakından izlemeleri ve bu uygulamaların etkilerine yönelik araştırmalar yapmaya yönlendirilmesi gerekmektedir. Tamamlayıcı ve integratif yaklaşımların semptom yönetiminde daha sık kullanılabilmesi ve uygulama alanına aktarılabilmesi için HD hastalarının teşvik edilmesi de alana önemli katkılar sağlayabilecektir.

Çıkar Çatışması: Bildirilmemiştir.

Finansal Destek: Yoktur.

Yazar katkıları

Çalışma tasarımı: ZGM, HE

Literatür araştırması: HE, ZGM

Makalenin hazırlanması: HE, ZGM

Confict of Interest:Not reported.

Funding: None.

Author contributions:

Study design: ZGM, HE

Literature research: $\mathrm{HE}, \mathrm{ZGM}$

Drafting manuscript: $\mathrm{HE}, \mathrm{ZGM}$

\section{KAYNAKLAR}

1. Akyol Güner T, Erdoğan Z, Özdemir B, Çoban G, Aksu N. Kronik böbrek yetmezliği hastalarının bakım vericilerinin yaşam kalitesi. Nefroloji Hemşireliği Dergisi. 2018;13(2):91-7.

2. Lukela JR, Harrison RV, Jimbo M, Mahallati A, Saran R, Sy AZ. UMHS Chronic Kidney Disease Guidelines. Michigan: 2019. Management of chronic kidney disease; p. 21-34.

3. Varol E, Karaca Sivrikaya S. Kronik böbrek yetmezliğinde yaşam kalitesi ve hemşirelik. DÜ Sağlık Bil Enst Derg. 2018;8(2):89-96.

4. Süleymanlar G, Altıparmak M, Seyahi N. Türkiye'de nefroloji, diyaliz ve transplantasyon. Ankara: Miki Matbaacılık; 2019. Hemodiyaliz; s. 7-28.

5. Himmelfarb J, Ikizler TA. Hemodialysis. N Engl J Med. 2010;363(19):1833-45.

6. Tuna D, Ovayolu N, Kes D. Hemodiyaliz hastalarında sık karşılaşılan problemler ve çözüm önerileri. Nefroloji Hemşireği Dergisi. 2018;13(1):17-25.

7. Flythe JE, Powell JD, Poulton CJ, Westreich KD, Handler L, Reeve BB, et al. Patient-reported outcome Instruments for physical symptoms among patients receiving maintenance dialysis: A systematic review. Am J Kidney Dis.2015;66:1033-46.

8. Flythe JE, Hilliard T, Lumby E, Castillo G, Orazi J, AbdelRahman EM, et al. Fostering Innovation in symptom management among hemodialysis patients. Clin J Am Soc.Nephrol.2019;14:150-60.
9. Flythe JE, Hilliard T, Castillo G, Ikeler K, Orazi, J, AbdelRahman EM, et al. Symptom prioritization among adults receiving in-center hemodialysis. Clin J Am Soc Nephrol. 2018;13:735-45.

10. Ovayolu N, Ovayolu Ö, Güngörmüş Z, Karadağ G. Böbrek yetmezliğinde tamamlayıcı tedaviler. Nefroloji Hemşireliği Dergisi. 2015;10(1):40-6.

11. Rao A, Phaneendra D, Pavani CD, Soundararajan P, Rani NV, Thennarasu P, et al. Usage of complementary and alternative medicine among patients with chronic kidney disease on maintenance hemodialysis. J Pharm Bioallied Sci. 2016;8(1):52-7.

12. Jeon $\mathrm{HO}$, Kim BH, Kim O. Illness uncertainty and complementary and alternative medicine use in patients undergoing hemodialysis. Nurs Health Sci. 2019;21(3):375-81.

13. Balouchi A, Masinaeinezhad N, Abdallahimohammad A, Firouzkouhi M, Sepehri Z. Comparison of effects of orange and lavender extract on fatigue in hemodialysis patients. Der Pharmacia Lettre. 2016;8(7):148-52.

14. Bouya S, Ahmadidarehsima S, Badakhsh M, Balouchi A. Effect of aromatherapy interventions on hemodialysis complications: A systematic review. Complementary Therapies in Clinical Practice. 2018;32:130-8.

15. Higgins J, Altman D, Sterne J. Cochrane handbook for systematic reviews of interventions version 5.1.0. Higgins JPT, Green S, editors. Assessing risk of bias in included studies. The Cochrane Collaboration; 2011.

16. Hadadian F, Sohrabi N, Farokhpayam M, Farokhpayam $H$, Towhidi F, Fayazi S, et al. The effects of transcutaneous electrical acupoint stimulation (TEAS) on fatigue in haemodialysis patients. J Clin Diagn Res. 2016;10(9):1-4.

17. Kılıç Akça N, Taşcı S. Acupressure and transcutaneous electrical acupoint stimulation for improving uremic pruritus: A randomized, controlled trial. Alternative Therapies. 2016;22(3):18-24.

18. Tsai MY, Wu CH, Huang YC, Chen SY, Ng HY, Su YJ, et al. Treatment of intradialytic hypotension with an herbal acupoint therapy in hemodialysis patients: A randomized pilot study. Complementary Therapies in Medicine. 2018;38(2018):67-73.

19. Shahgholian N, Dehghan M, Mortazavi M, Gholami F, Valiani M. Effect of aromatherapy on pruritus relief in hemodialysis patients. Iran J Nurs Midwifery Res. 2010;15(4):240-44.

20. Biçer S, Ünsal A, Demir G. The effect of aromatherapy massage applied to facial area upon headache severity among patients who suffered from headache during hemodialysis. International Journal of Caring Sciences. 2015;8(3):722-28.

21. Efe Arslan D, Kılıç Akça N. The effect of aromatherapy hand massage on distress and sleep quality in hemodialysis patients: A randomized controlled trial. Complementary Therapies in Clinical Practice. 2020;39(2020):101-36. 
22. Varaei S, Jalalian Z, Nejad MSY, Shamsizadeh M. Comparison the effects of inhalation and massage aromatherapy with lavender and sweet orange on fatigue in hemodialysis patients: A randomized clinical trial. Journal of Complementary Integrative Medicine. (in press). 2020. https://doi.org/10.1515/jcim-20180137

23. Mahdavi A, Gorji MAH, Gorji AMH, Yazdani J, Ardebil MD. Implementing Benson's relaxation training in hemodialysis patients: Changes in perceived stress, anxiety, and depression. N Am J Med Sci. 2013;5(9):536-40.

24. Gorji MAH, Davanloo AA, Heidarigorji AM. The efficacy of relaxation training on stress, anxiety, and pain perception in hemodialysis patients. Indian J Nephrol. 2014;24(6):356-61.

25. Rambod M, Pourali-Mohammadi N, Pasyar N, Rafii F, Sharif $F$. The effect of Benson's relaxation technique on the quality of sleep of Iranian hemodialysis patients: A randomized trial. Complementary Therapies in Medicine. 2013;21(6):577-84.

26. Rambod M, Sharif F, Pourali-Mohammadi N, Pasyar N, Rafii F. Evaluation of the effect of Benson's relaxation technique on pain and quality of life of hemodialysis patients: A randomized controlled trial. International Journal of Nursing Studies. 2014;51(7):964-73.

27. Koushan $M$, Rakhshani $M H$, Mohsenpour $M$, Heshmatifar $\mathrm{N}$. The effect of Benson relaxation response hemodialysis patients' fatigue. JSUMS. 2014;20(5):757-65.

28. Heshmatifar N, Sadeghi H, Mahdavi A, Nakhaie MRS, Rakhshani $\mathrm{MH}$. The effect of Benson relaxation technique on depression in patients undergoing hemodialysis. JBUMS. 2015;17(8):34-40.

29. Otaghi M, Borji M, Bastami S, Solymanian L. The effect of Benson's relaxation on depression, anxiety and stress in patients undergoing hemodialysis. Int J Med Res Health Sci. 2016;5(12):76-83.

30. Hassanzadeh M, Kiani F, Bouya S, Zarei M. Comparing the effects of relaxation technique and inhalation aromatherapy on fatigue in patients undergoing hemodialysis. Complementary Therapies in Clinical Practice. 2018;31(2018):210-4.

31. Meawad Elsayed EB. The effect of Benson's relaxation technique on anxiety, depression and sleep quality of elderly patients undergoing hemodialysis. International Journal of Nursing Didactics. 2019;09(02):23-31.

32. Hasankhani H, Ghaderi F, Lakdizaji S, Nahamin M. The effect of the slow-stroke back massage on fatigue of dialyzed patients. Intl. Res. J. Appl. Basic. Sci. 2013;4(10);3004-8.

33. Mortazavi $H$, Arian $M$, Ebrahimi $H$, Tabatabaeichehr $M$, Binesh $M$, Varvani FA. Effects of effleurage massage on intensity of physiological stress associated with the treatment in hemodialysis patients. Repository of Research and Investigative Information. 2016;11(1);24-31.
34. Mastnardo D, Lewis JM, Hall K, Sullivan CM, Cain K, Theurer J, et al. Intradialytic massage for leg cramps among hemodialysis patients: A pilot randomized controlled trial. Int J Ther Massage Bodywork. 2016;9(2):3-8.

35. Ünal KS, Balcı Akpınar R. The effect of foot reflexology and back massage on hemodialysis patients' fatigue and sleep quality. Complementary Therapies in Clinical Practice. 2016;24(2016):139-44.

36. Ahmadidarrehsima S, Mohammadpourhodki R, Ebrahimi $\mathrm{H}$, Keramati $\mathrm{M}$, Dianatinasab M. Effect of foot reflexology and slow stroke back massage on the severity of fatigue in patients undergoing hemodialysis: A semi-experimental study. Journal of Complementary Integrative Medicine. 2018;15(4):1-6.

37. Thomas Z, Novak M, Platas SGT, Gautier M, Holgin AP, Fox $R$, et al. Brief mindfulness meditation for depression and anxiety symptoms in patients undergoing hemodialysis: A pilot feasibility study. CJASN. 2017;12 (12):2008-15.

38. Bassirimoghadam M, Madadkardehkordi S, Mohammadpour A. Effect of progressive muscle relaxation technique on fatigue inpatients undergoing hemodialysis. Preventive Care in Nursing Midwifery Journal. 2014;3(2):24-32.

39. Amini E, Goudarzi I, Masoudi R, Ahmadi A, Momeni A. Effect of progressive muscle relaxation and aerobic exercise on anxiety, sleep quality, and fatigue in patients with chronic renal failure undergoing hemodialysis. IJPCR. 2016;8(12):1634-39.

40. Kaplan Serin E, Ovayolu N, Ovayolu Ö. The effect of progressive relaxation exercises on pain, fatigue, and quality of life in dialysis patients. Holistic Nursing Practice. 2020;34(2):121-8.

41. Özdemir G, Ovayolu N, Ovayolu Ö. The effect of reflexology applied on haemodialysis patients with fatigue, pain and cramps. International Journal of Nursing Practice. 2013;19(3):265-73.

42. Aliasgharpour M, Nejati S, Hasani SA, Saatchi K, Kazemnejad A. Comparison of foot and hand reflexology on fatigue in patients undergoing hemodialysis. Health Breeze. 2014;3(2):9-15.

43. Roshanravan $M$, Jouybari L, Bahrami TH, Vakili $M$, Sanagoo A, Amini Z. Effect of foot reflexology on fatigue in patients undergoing hemodialysis: A shamcontrolled randomized trial. J Mazandaran Univ Med Sci. 2016;26(137):32-41.

44. Izadpanah AM, Hadavi M, Bahrami THR. The effect of foot reflexology on severity of fatigue in hemodialysis patients. Journal of Sabzevar University of Medical Sciences. 2018;25(4):581-90.

45. Emamverdi M, Mohammadpour A, Badiee AS, Sajjadi $M$. Comparing the effects of reflexology massage and acupressure on the quality of sleep in hemodialysis patients: A randomized clinical trial. Journal of Mazandaran University of Medical Sciences. 2019;29(176):34-46.

46. Naseri SV, Sajadi M, Abedi A, Fournier A, Saeidi N. Reflexology as an adjunctive nursing intervention for 
management of nausea in hemodialysis patients: A randomized clinical trial. Complementary Therapies in Clinical Practice. 2019;36(2019):29-33.

47. Kurt B, Kapucu S. Meme kanserli hastalarda progresif gevşeme egzersizlerinin kemoterapi semptomlarına etkisi: Literatür derlemesi. Mersin Univ Saglık Bilim Derg. 2018;11(2):235-49.

48. Bagheri Nesami M, Mohseni Bandpei AM, Masoud Shayesteh A. The effect of Benson relaxation technique on rheumatoid arthritis patients: Extended report. Int J Nurs Pract. 2006;12(4):214-9.

49. Fayazi S, Shariati AAA, Momeni M. The efficacy of Benson's relaxation technique on postoperative pain in coronary artery bypasses graft. Jundishapur Scientific Medical Journal. 2010;8(4):479-89.

50. Ngo TH. Review of the effects of mindfulness meditation on mental and physical health and its mechanisms of action. Sante Ment Que. 2013;38(2):19-34.

51. Liao IC, Wang MY, Chung YC, Tsai PS. Effects of Swedish massage on blood pressure lowering in patients with pre-hypertension and stage-I hypertension: A preliminary study. Airiti Library. 2016;18(2):11-23.

52. Metin ZG, Ozdemir L. Using aromatherapy and reflexology for pain and fatigue management in rheumatoid arthritis. Journal of Education and Research in Nursing. 2016;13(1):276-82. 